\title{
From Russia With Love: Dissidents, Defectors and the Politics of Asylum in Cold War India
}

\author{
Paul M. McGarr \\ Department of American and Canadian Studies \\ University of Nottingham \\ University Park \\ Nottingham NG7 2RD \\ Tel. 01158232265 \\ paul.mcgarr@nottingham.ac.uk
}

ORCID ID: orcid.org/0000-0002-0684-7611

Paul McGarr is Associate Professor in US Foreign Policy at the University of Nottingham. He is the author of The Cold War in South Asia: Britain, the United States and the Indian Subcontinent, 1945-1965 (Cambridge University Press, 2013). He has published on Anglo-American relations with post-independent South Asia in Diplomatic History, The International History Review, Modern Asian Studies, Diplomacy \& Statecraft, The Journal of Imperial and Commonwealth History, and History. He is currently completing a second monograph that examines connections between US Intelligence activity and American diplomacy in South Asia, a nexus of the ongoing 'War on Terror'. 


\title{
From Russia With Love: Dissidents, Defectors and the Politics of Asylum in Cold War India
}

\author{
Abstract
}

During the Cold War defectors were invariably paraded as propaganda trophies. The wider political significance of defections has hitherto been interrogated almost exclusively in an East-West binary. Utilizing recently declassified documents from three continents, attention is focused on the elided role played by the developing world in the Cold War asylum story and, specifically, that of non-aligned India. By reinterpreting international responses to three Soviet defections that occurred in India in the 1960s, new light is shed upon political asylum as a source of North-South tension and discord.

Keywords: Defection; Asylum; India; Cold War; Soviet Union.

In January 1968, Suman Mulgaokar, editor of the influential Indian daily, the Hindustan Times, published an editorial entitled, 'The Right of Asylum.' Mulgaokar was an acerbic critic of the ruling Congress Party's left-leaning socio-economic policies and pragmatic approach towards authoritarian Eastern bloc Communist regimes. His interest in political asylum was piqued by a series of high-profile incidents that saw nationals from behind the Iron Curtain seek refuge in the Indian capital's Western missions. Mulgaokar's newspaper had, wittingly or not, served as a vehicle for the dissemination of Western counterpropaganda designed to weaken Communist influence in the subcontinent. Back in 1964, the British Information Research Department (IRD), a shadowy covert information arm of the Foreign Office with close links to MI6, or the British Secret Intelligence Service (SIS), recorded with satisfaction that the Hindustan Times had, "not been inactive on our behalf recently." Four years later, in noting the consternation that Cold War defections had engendered in Indian government circles, Mulgaokar observed wryly that:

To have three Russian defections occur in your country within three years is embarrassing enough. When one of the defectors is Stalin's daughter, the matter gets much worse. When the third of the defectors...goes about stating that...he had 'chosen' India to defect from because visas for India were relatively easy to obtain, the unusually high colour of Indian Home and External Affairs Ministry officials becomes easy to understand. ${ }^{2}$

Less easy to comprehend, in Mulgaokar's opinion, was an aide memoire that the Indian Government circulated to diplomatic missions in New Delhi on 30 December 1967. Originating in the Ministry of External Affairs (MEA), the note stated that it 
was, 'well established that the affording of asylum is not within the purposes of a Diplomatic Mission'. Should any Mission receive a request for asylum, the MEA directive added, it should be refused. ${ }^{3}$ The instruction backed Indian officials into an awkward corner. Were the American or the Soviet embassies to take in a defector, Mulgaokar observed, the MEA faced, 'the choice of either doing nothing, which would make it look impotent, or of invading the Embassy premises which would be a violation of the conventions of courtesy between nations.' In respect of low-level and largely benign political refugees, the adoption of such a rigid policy appeared unnecessarily punitive and counterproductive. It made little sense in such cases, Mulgaokar opined, 'for India to get into a flap merely because its soil was used to stage the defection. ${ }^{4}$

The Indian government's decision to issue a directive on political asylum was triggered by the defection of Aziz Saltimovitch Ulug-Zade, an Indologist at Moscow State University. Ulug-Zade had travelled to India as part of a Soviet Komsomol group, or political youth delegation. On 19 December 1967, just hours before he was due to return home, Ulug-Zade walked out of the Hotel Ranjit in New Delhi, hailed a taxi, and made for the British High Commission in the diplomatic enclave of Chanakyapuri. Having been turned away by the British, Ulug-Zade moved on the American embassy. The Americans proved more welcoming. To the fury of the MEA and Soviet diplomats, the US ambassador, Chester Bowles, offered Ulug-Zade sanctuary and agreed to assist his defection to the West. ${ }^{5}$ Diplomatic tensions over the Ulug-Zade affair escalated rapidly. In the Indian press, Soviet officials charged their American counterparts with kidnapping the young Russian. Finding itself caught in the middle of a dispute involving the United States, Britain, and the Soviet Union, an alarmed Indian government saw its relationships with all three countries, and its domestic credentials as a safe haven for victims of political persecution, come under pressure. Above all, the MEA worried that India's acquisition of an unwelcome reputation as a Cold War clearing-house, or the 'Berlin of the East', threatened serious harm to the nation's international relations. ${ }^{6}$

In the 1960s, the Indian government was embroiled in a succession of diplomatic rows surrounding defections from East to West. Notably, the Ulug-Zade case had been preceded a few months earlier by an incident that dominated global news headlines. In March 1967, Svetlana Iosigovna Alliluyeva, the only daughter of the former Soviet dictator, Joseph Stalin, defected to the United States through India. Five years before, in the autumn of 1962, Vladislaw Stepanovich Tarasov, a twenty-fiveyear-old Soviet merchant seaman, jumped ship in the eastern Indian port of Kolkata. After a protracted legal wrangle in the Indian courts, that saw New Delhi entangled in an acrimonious stand-off between Moscow and Washington, the Russian sailor departed from the subcontinent to a new life in the West. The Tarasov episode occurred at a point when India was reeling from a humiliating military defeat in a border war with the People's Republic of China, and New Delhi was actively courting American and Soviet support against Beijing. More broadly, defections staged in India served as an unwelcome irritant in relations between the Soviet Union, the United States, and Great Britain, when these countries were attempting to defuse global tensions and forge more productive ties in the wake of the Cuban Missile Crisis. The decade between the Sino-Indian border war of 1962, and the IndoPakistan conflict of 1971, witnessed India distance itself from the West, and strengthen its relationship with the Soviet Union. In this context, Indian governments found themselves scrambling to contain diplomatic fallout from defections staged on their soil that threatened to undermine a strategic tilt towards Moscow. 


\section{India, Non-Alignment and Political Asylum}

The significance of nonaligned states and, more specifically, India, in the transnational story of Cold War asylum, has been obscured by a tendency on the part of historians and producers of popular culture to approach questions surrounding defection in an East-West binary. ${ }^{7}$ The scant attention given to defections that occurred inside the developing world has largely privileged individual narratives, and marginalized or ignored the role and agency of Asian and African nations. ${ }^{8}$ This article shifts the prevailing axis of the Cold War asylum debate to examine the impact of dissidents and defections from a North-South perspective. It is informed by the recent work of Odd Arne Westad, Robert McMahon, and Paul Thomas Chamberlain, that reinterprets the Cold War as a global conflict. ${ }^{9}$ From the early 1950 s, ideological and socio-political prescriptions for modernity and progress advanced by Washington and Moscow were buffeted by local forces across the Global South. To their discomfort, the superpowers discovered that the politics of Cold War asylum in India required a measure of pragmatism and compromise to be exercised on all sides, and not merely on the part of New Delhi.

Defections placed considerable strain on the policy of Cold War non-alignment practiced by states such as India. Of late, scholarship undertaken by Itty Abraham, Nataša Mišković, and Christopher Lee, has emphasised how Western neocolonialism, and the interventionism of Moscow and Washington, intersected with the Non-Aligned Movement (NAM). ${ }^{10}$ As Lorenz Lüthi has noted, 'Although the NonAligned Movement tried to transcend the Cold War, its foundation in 1961 was triggered, and its first dozen years were shaped, by the superpower conflict. ${ }^{11}$ In the case of India, the period beginning with the inauguration of the NAM, in Belgrade, at the start of the decade, and culminating with the organisations gathering in Algiers, in 1973, saw New Delhi's adherence to non-alignment stretched thin and, eventually, snap. The policy drivers that lay behind India's move toward the Soviet orbit during this period are manifold. An escalation in tension with the United States over issues as diverse as the Vietnam War, food aid, and Bangladesh's emergence as a nation state, all contributed to New Delhi's decision to effectively abrogate non-alignment, and enter into a security pact with the Soviet Union in 1971. Yet, the record of East-West defection in the subcontinent during a tumultuous period in its recent history suggests that India was as much an active participant in the demise of non-alignment in South Asia, as it was a hapless victim.

This paper reperiodizes the issue of political asylum. To date, a preponderant focus has been placed on early Cold War defections, such as those of Guy Burgess, Donald Maclean, and Kim Philby, members of the so-called 'Cambridge Five' spy ring. ${ }^{12}$ Equally, much has been made of espionage activity and political asylum in the later Cold War period, when the process of détente faltered, and East-West tensions intensified following the Soviet invasion of Afghanistan, in December 1979. ${ }^{13}$ Yet, from the late-1950s onwards, the politics of defection entered a new temporal and geographic phase. Defections staged in Europe slowed as border controls between East and West Germany were tightened and, in 1961, the Berlin Wall went up. Concurrently, applications for political asylum multiplied at points of Cold War intersection outside Europe. The numbers of 'non-returnees' from Eastern bloc delegations visiting Asia increased, and incidents of 'jumpers', or absconders, from Soviet ships visiting ports across the developing world, grew. ${ }^{14}$ Before long, such shifts in the pattern of defections was mirrored in popular culture. In the early 1970s, the novel, Tinker, Tailor, Soldier Spy, penned by the eponymous espionage author, 
and one-time member of the British secret State, John Le Carrè, situated a Soviet defection episode not in the well-worn literary borderlands between East and West Germany, but in New Delhi. ${ }^{15}$

In a sense, it is understandable that so little attention has been paid within Cold War narratives to incidents of defection and political asylum that occurred in the context of decolonization. Historical enquiry in this area has traditionally been hampered by government secrecy surrounding the processes for identifying would-be Cold war defectors, the roles played by intelligence and security services in facilitating defection, and state management of publicity and diplomatic blowback in asylum cases. In this analysis, to minimise the impact of such restrictions, recently released material from state archives in the United Kingdom, the United States, and India, has been triangulated with private papers and secondary sources to provide the clearest picture yet of the impact of Cold War defection on India's international relations. Specifically, the declassification, early in 2019, of new material from the Information Research Department has significantly augmented the existing British record covering defection that has been drip-fed to researchers since the 1990s. In addition, in the United States, the opening of previously embargoed Cold War records by the Central Intelligence Agency (CIA), and within the presidential library system, most especially papers held by the Lyndon Johnson and Gerald Ford Libraries, have transformed understanding of American responses to prominent political asylum cases. Likewise, it is only very recently that important Indian material relating to defection and asylum has become available for public consultation at the National Archives of India and the Nehru Museum and Memorial Library, in New Delhi.

Considerable obstacles remain to scholars attempting to navigate the history of Cold War defection in South Asia. Not least, in keeping with the policy of Britain's SIS, India's intelligence agencies and, above all, the nation's external intelligence service, the Research and Analysis Wing (R\&AW), have kept their organisational archives firmly closed. Back in 2004, one leading intelligence historian noted that the British government had, 'fought a long campaign to ensure that much of the history of its intelligence services remains secret.' 16 The same could be said of the United States and India. Nonetheless, while notable records of the covert Cold War in the UK, US, and South Asia remain elided, matters have improved considerably over the last two decades in terms of state transparency. ${ }^{17}$ It has now become possible, for the first time, to write comprehensive accounts of India's secret Cold War that are informed by official documentation sourced from three continents. ${ }^{18}$

Moreover, this paper circumvents limitations imposed by official secrecy to recover the importance of hitherto marginalized non-state actors to the global history of Cold War defection and political asylum. Inside the Global South, human rights activists, lawyers, and journalists, competed alongside and, on occasions, collaborated with, the intelligence services and covert propaganda agencies of the Western and the Eastern blocs to shape popular attitudes and influence national. For much of the Cold War period, the Indian state adopted a proactive, if not altogether successful approach to managing the domestic politics of political asylum. Concerned that defections on its territory would disrupt India's relationships with important international partners and exacerbate internal fissures, New Delhi was anything but a passive player in the high drama of Cold War asylum.

From a domestic standpoint, when framing approaches to political asylum, Indian governments came under sustained pressure from a robust national press, the judiciary, and querulous parliaments. Indigenous elements on both the left and the right of India's political spectrum approached the question of asylum as an 
opportunity to orientate the nation's foreign policy. In a colonial context, scholars elsewhere have stressed the importance of the Indian media to the struggle for Independence, and noted British efforts to coopt the subcontinent's press in a counterpropaganda campaign designed to sustain imperial rule. ${ }^{19}$ Less emphasis has been placed on the extent to which Indian perceptions of the press as guardians of individual liberties continued to impact national politics in respect of defection and asylum after 1947. As will become evident, Western Cold War propagandists worked secretly with sympathetic Indian publishers, journalists, and newspaper editors, to leverage debates surrounding political asylum in a bid to arrest what policymakers in London and Washington saw as an alarming lurch to the left by New Delhi, both at home and abroad.

Moreover, by privileging previously marginalized Indian agency, this paper looks to complicate established accounts of the emergence of a human rights dimension of international diplomacy. In the case of India, tensions between domestic and international considerations surrounding questions of dissidents, political asylum, and the application of universal human rights, directly informed policy decisions taken from the very foundation of the Indian Republic. ${ }^{20}$ One legacy of India's anti-imperial struggle, and the oppressive security apparatus employed by the British colonial state to frustrate it, was an antipathy towards work performed by intelligence agencies and a corresponding emphasis on freedom of expression and individual liberty. ${ }^{21}$ Indian policymakers were confronted by competing demands to evidence a liberal approach to political asylum while, at the same time, upholding national security by remaining on good terms with both Cold War blocs.

In attempting to navigate the treacherous waters of Cold War defection, India's leaders were not helped by the persistence of disagreements within the international community over the legal and moral obligations of states in respect of political asylum. The inviolability of diplomatic premises had been generally accepted by European states as far back as the medieval period. The right of missions to grant individuals asylum, although not always welcomed by local authorities, was invariably upheld. From the early 1950s, however, the International Court of Justice (ICJ) sought to draw a distinction between diplomatic asylum, or asylum which one state grants through a mission located within the territory of another, and territorial asylum, or asylum granted within the borders of the state offering sanctuary. Controversially, the ICJ concluded that diplomatic asylum had no standing in general customary law. Subsequent attempts by the United Nations to codify a universally accepted position on political asylum faltered. ${ }^{22}$ Well into the $1960 \mathrm{~s}$, the legal terrain surrounding political asylum remained a matter of dispute.

Beset by diplomatic exigencies, domestic pressures, and legal ambiguities, Indian leaders found it all but impossible to reconcile the domestic and international demands imposed by Eastern bloc defections staged in the subcontinent. Such events threatened to upset a fragile equilibrium underpinning New Delhi's relations with Washington and Moscow, and represented a headache to policymakers in India, the United States, and the Soviet Union. As the Cold War's battle-lines solidified in Europe in the 1960s, and an era of East-West détente got underway, it was in Asia that the issue of political asylum coalesced with regional conflicts and domestic power struggles to endanger an uneasy accommodation between the superpowers. The scandals, uncomfortable parliamentary questions, and press scrutiny of security and intelligence activity that habitually accompanied defections staged in Europe in the 1950s were, as we shall see, replicated a decade later in India. 


\section{Asylum Central: Becoming the 'Berlin' of the East}

Western governments took a robust line during the Cold War, in public at least, on the moral imperative of extending asylum to political dissidents. Indian administrations saw things rather differently. In 1959, confronted by widespread Indian sympathy for the plight of Tibetans subject to the imposition of Chinese rule, Jawaharlal Nehru, India's premier, offered asylum to Tibet's spiritual leader, the Dalai Lama, and thousands of his supporters, following an abortive insurrection. At the same time, India's Ministry of External Affairs made it clear to the UN Commission on Human Rights that the country lacked the economic capacity and infrastructure to accommodate further political refugees. Nor, given New Delhi's commitment to nonalignment, were Indian policymakers inclined to do so, and run the risk of becoming embroiled in arguments between the superpowers. ${ }^{23}$ Tensions between India's national security and popular support for a liberal political asylum policy were brought sharply home by the Dalai Lama episode. Incensed that India had provided Tibetan exiles with a safe haven from which to conduct anti-Chinese activities, and suspicious that New Delhi was colluding with the CIA to foment unrest inside Tibet, Beijing took a dim view of what it saw as an unwarranted intrusion into its internal affairs. ${ }^{24}$ In April 1960, having travelled to India for talks with Nehru, China's premier, Zhou Enlai, underlined the extent to which the two states' differing interpretations of political asylum had poisoned bi-lateral relations. Admonishing his Indian hosts, Zhou made clear that while Beijing had 'no objection' to the principle of political asylum, 'the Dalai Lama is today carrying out anti-Chinese activities and encouraging the movement for an independent Tibet. This is beyond the definition of political asylum. ${ }^{25}$

Zhou's protest underscored the broader point made by Indian journalists that had equated New Delhi with Berlin, framing the former as a Cold War city, where East met West, and espionage and intrigue were endemic. India's nonalignment did attract large diplomatic and commercial missions from both sides of the Iron Curtain. This was hardly unique. Other cities inside the non-aligned orbit, and notably Cairo, Jakarta, and Belgrade were, at various times, focal points for covert East-West competition. The Cold War's shifting geography, however, guaranteed that India would assume an especially prominent role as a clearing-house for defectors. Directly to the north of the subcontinent lay the communist colossuses of the Soviet Union and the People's Republic of China. In 1955, an exchange of state visits between Nehru and the Soviet leader, Nikita Khrushchev, invigorated moribund Indo-Soviet relations. Soviet economic and technical assistance to India boomed, while politically Moscow courted Indian goodwill by throwing its weight in the UN Security Council behind New Delhi's claim on the disputed state of Kashmir. By the end of Dwight D. Eisenhower's second presidential term, in January 1961, Washington had become alarmed by the extension of Soviet influence in India, and the strength of indigenous communism in the subcontinent. Eisenhower's efforts to bring India and the United States closer together, primarily through the provision of American economic assistance, were amplified by his successor, John F. Kennedy. Kennedy saw democratic India as a crucial strategic counterweight to the expansion of communism. For a time at the beginning of the sixties, the locus of Washington's effort to prevent Asia turning Red was centered not in South Vietnam or South Korea, but in South Asia. ${ }^{26}$ The neutral political space afforded by Indian non-alignment combined with the presence on the ground of thousands of government officials and functionaries from the United States and the Soviet Union, acted as magnet for would-be-asylum 
seekers.

The Berlin analogy was also symptomatic of the extent to which foreign intelligence agencies had come to value India as an operational theatre. The former British SIS officer, and Soviet spy, George Blake, observed that alongside Berlin, India ranked highly in Western intelligence circles as it offered, 'the most favourable conditions...for establishing contacts with Soviet citizens.' The presence in India of so many diplomats, non-governmental organisations, technicians, businesspeople, and journalists from the Soviet Union, Britain, and the United States provided ample scope for encouraging defections. In New Delhi, Blake underlined, 'there was a wider intercourse than elsewhere between Soviet diplomatic personnel and local politicians and public and it would be easier therefore for our [SIS] agents to establish contact with them.'27

What applied to SIS, also held true for the CIA, and Soviet intelligence bodies, such as the Committee for State Security (KGB) and GRU, or foreign military intelligence. By the 1960s, the CIA had a sizable, growing, and active in-country presence in India. Having begun operations from a single 'station,' or office, in New Delhi, the Agency extended the geographical scope of its activities, establishing a network of out-stations in Mumbai, Kolkata, and Chennai. One U.S. diplomat later attested that the intelligence footprint in India was, "very large, and very invasive . . . the CIA was deeply involved in the Indian Government. ${ }^{28}$ Indeed, Indian politicians, government officials, and intelligence officers had occasion to collaborate with the CIA, and other foreign intelligence services, when it suited their interests to do so. Specifically, the Indian government elected to 'look the other way' as CIA aircraft violated its airspace in support of Agency sponsored resistance activities in Chinese controlled Tibet. Likewise, New Delhi tacitly approved a CIA-sponsored operation to spirit the Dalai Lama out of Lhasa and into northern India. ${ }^{29}$

At the same time, a series of young and dynamic KGB chairman, including Alexander Shelepin, Vladimir Semichastny, and the future Soviet leader, Yuri Andropov, enthusiastically supported Moscow's policy of fermenting wars of national liberation, and undermining Western influence across the Global South. Under Andropov's direction, Soviet foreign intelligence agencies concentrated a large proportion of their resources, outside of Europe and North America, on India. ${ }^{30}$ Oleg Kalugin, then a rising star in the KGB's First Chief (Foreign Intelligence) Directorate, confirmed that, toward the end of the 1960s, the KGB 'had scores of sources throughout the Indian government - in intelligence, counterintelligence, the defense and foreign ministries, and the police. The entire country was seemingly for sale, and the KGB and the CIA had deeply penetrated the Indian government.' 31

Within India, public perceptions that defectors were welcome, and would be treated sympathetically as victims of political persecution, belied the fact that national governments often approached the issue of asylum as an unwanted irritant. Some intelligence historians have contended that, 'encouraging and exploiting defection...was a constant component of US policy toward the USSR throughout the Cold War. ${ }^{32}$ Yet, paradoxically, as Western intelligence services hatched plans to stimulate defections, the politicians that they served frequently recoiled from the diplomatic tensions such activity fostered. ${ }^{33}$ A majority of the defectors moving from East to West were of limited value in intelligence terms. ${ }^{34}$ Likewise, the propaganda bonanza associated with parading defectors before the world's media was invariably offset in the minds of politicians by the potential such events carried to upset broader foreign policy objectives. 
The mere mention of defection induced neuralgic episodes in British premiers such as Winston Churchill and Harold Macmillan. ${ }^{35}$ In 1954, Churchill expressed alarm that the defection of a KGB officer, Nikolai Khokhlov, would undermine that year's Geneva summit, at which Britain, France, China, Russia, and the United States met to discuss the fate of Indochina, and the wider Cold War in Asia. Churchill's ultimately abortive plan to exploit the death of Joseph Stalin, which had occurred the previous year, and engineer a thaw in the Cold War, led the British prime minister to veto an SIS request to publicise Khokhlov's defection. ${ }^{36}$ Moreover, a dramatic escape to the West that played out at the same time in Australia, and involved Vladimir Petrov, a colonel in KGB, provoked a schism in Canberra's relations with Moscow. Piqued by Petrov's defection, the Soviets waited five years before restoring full diplomatic relations with Australia. ${ }^{37}$

Although America's politicians were generally less squeamish about the pitfalls of embarrassing Moscow by exploiting defectors for propaganda purposes, US President's did find good cause to rue the politics of political asylum. In 1975, Gerald Ford became enmeshed in a damaging domestic controversy involving the Soviet dissident, and author of the acclaimed Gulag Archipelago, Alexander Solzhenitsyn. In the midst of a period of US-Soviet détente, Ford found himself excoriated by Democrats and Republicans for bowing to pressure from Moscow, and refusing to meet with Solzhenitsyn. ${ }^{38}$ In a South Asian context, as we shall see, the politics of Cold War asylum meant that Soviet defectors could prove just as unpopular in New Delhi, London, or Washington, as they were in Moscow.

\section{Vladislav Tarasov and the 'Other' Crisis of Autumn 1962}

On the evening of 25 November 1962, global tensions ran high. The superpowers were observing an uneasy truce in the immediate aftermath of the Cuban Missile Crisis. In India, a shell-shocked nation licked its wounds following a humbling military defeat at Chinese hands in a short but bloody border war. Amidst a febrile international atmosphere, the actions of a young Russian sailor in the subcontinent ignited a political storm, setting off a chain of events that placed India at the centre of global debates on political asylum. Under cover of darkness, Vladislav Stepanovich Tarasov, a young merchant seaman from the Ukraine, climbed out of a porthole on the Tchernovtei, a Soviet oil tanker anchored in Kolkata's King George's docks, and swam to a nearby American ship, the SS Steel Surveyor. Once aboard the American vessel, Tarasov, clad only a pair of swimming trunks, announced that his life was in danger, and asked the ship's captain for political asylum. ${ }^{39}$

The Soviet defector claimed to have become disenchanted with restrictions on personal freedoms behind the Iron Curtain. In a series of public statements crafted by America's Cold War propagandists, Tarasov subsequently proclaimed that after listening to Voice of America broadcasts, and reading copies of America, a US magazine distributed in the Soviet Union under a cultural exchange agreement, he had determined to seek a new life in the United States. ${ }^{40}$ In fact, the Russian sailor, who had a wife and young child back home in the USSR, had a troubled marriage, a history of complaining about pay and working conditions in the Soviet merchant fleet, and had fallen foul of a political commissar assigned to the Tchernovtei. The discovery in Tarasov's possession of letters critical of the Soviet regime, and an accompanying threat from the commissar that the papers would preclude future trips abroad, provided the catalyst for an impromptu decision to defect. ${ }^{41}$ 
In an effort to prevent Tarasov's flight to the West, V. Londorev, the Soviet consul in Kolkata, informed the Indian authorities that the sailor had stolen a small sum of money from his ship before disembarking, was a common criminal, and should be arrested and extradited to the USSR. Tarasov's case was the first of its kind in India. The Soviets had never previously submitted a request to the Indian authorities for the extradition of one of their nationals. On 28 November, after the Soviets, somewhat improbably, provided twelve witnesses to Tarasov's 'crime', Indian policemen boarded the SS Steel Surveyor and removed the sailor to Kolkata's central prison. ${ }^{42}$ Acting on instructions from Washington, local American officials made clear that the United States regarded the Tarasov affair as political matter, that Soviet allegations of criminality were demonstrably false, and that the defector should be permitted to seek asylum in the West. ${ }^{43}$

The Indian government was aghast at being caught in the middle of a Cold War dispute between the United States and the Soviet Union at a time when India's very survival appeared to hinge on retaining the support of both superpowers in its conflict with China. The New York Times reflected that New Delhi had been thrown into a panic by, 'a Soviet sailor... put[ting] a new strain on India's embattled policy of nonalignment in the cold war by demanding asylum.... ${ }^{44}$ On 29 November, the Kolkata daily, Jugantar, or 'New Era', noted that '...the Government of India, now caught between the crossfire of two friendly governments, will not find it easy to take a decision on the issue. One of them [an Indian government official] remarked, "now it appears that a Sobolev has appeared in Calcutta [Kolkata]." "45 The allusion to Arkady Sobolev, a former Soviet ambassador to the United Nations in New York, underlined the concern that Indian officials harboured in relation to the Tarasov case. Sobolev had been at the centre of a diplomatic furore after he was charged by the US State Department with coercing five Russian sailors who had defected to the West into returning to the Soviet Union. ${ }^{46}$

To the Indian government's dismay, the Tarasov episode quickly descended into a high farce, every twist and turn of which was splashed across the pages of the world's press. Having twice been refused bail by local Indian magistrates, Tarasov, with American assistance, took his case to the Indian High Court. On 5 January, as Nehru's government came under intense pressure from both the Soviet and American embassies to intervene in the case, Tarasov was released on bail by an Indian judge and placed in the custody of Hugh Haight, a local US official. ${ }^{47}$ Back in Washington, the State Department poured scorn on Soviet attempts to portray Tarasov as a criminal and to deny that his actions were politically motivated. Referencing previous Soviet attempts to pin false legal charges on defectors, a State Department spokesman, Lincoln White, defended Tarasov, and reminded journalists pointedly that, 'we've heard of such charges [from Moscow] before. ${ }^{48}$ Indeed, in concert with colleagues in the IRD, American officials actively sought to leverage the world's media to secure Tarasov's defection. One IRD officer noted that the seaman's enforced return to the Soviet Union, 'would, inter alia, discourage other defections. We assume that TARASOV has useful information. It would appear that the best available means of accomplishing our objective is through international publicity. ${ }^{49}$

To Moscow's consternation, the Soviet case against Tarasov was compromised after embarrassed Russian officials discovered that a criminal act committed within Indian territorial waters did not constitute legal grounds for extradition. An Indian Extradition Act had passed through the country's parliament a few months previously, but it remained pending ratification when Tarasov sought asylum. In an exchange of diplomatic notes between Indian and Soviet officials in November and December, the 
MEA provided the Russians with a copy of the Extradition Act and, more significantly, indicated the precise evidence that an Indian magistrate would expect to see before approving a request for repatriation. ${ }^{50}$ By coaching the Soviets in the intricacies of Indian asylum law, the MEA created the impression of having sacrificed its impartiality in the pursuit of national security. Legal advice offered by the MEA to the Soviets was later decried by Indian jurists as tantamount to 'providing the Russians with a ready-made machine for achieving their object. ${ }^{51}$ On 10 January 1963, a Kolkata court dismissed the Soviet extradition motion against Tarasov. Emerging from the court a free man, Tarasov, in full view of a large contingent of international reporters, was immediately rearrested by the Indian authorities on the basis of fresh evidence provided by the Soviet embassy. Contrary to previous witness statements, and in line with the MEA's counsel, the Soviets now claimed that the alleged theft committed by Tarasov had, in fact, occurred on the high seas. ${ }^{52}$ The extradition case, which by now had assumed the appearance of a cause célèbre in the subcontinent's media, returned to India's courts.

In the background, local Soviet officials impressed upon the MEA the imperative of concluding legal proceedings swiftly, and before international press coverage of Tarasov's case compromised New Delhi's relations with Moscow. Apprehensive American diplomats confided to British colleagues that the Indian government was, 'under heavy Soviet pressure to hand him [Tarasov] back and may in fact do so.' The MEA had, the Americans suspected, 'probably imposed press censorship which would explain [an] absence of further reports on the subject.' In the circumstances, the Americans ensured that Indian officials were 'clear that they [the US] will promote widespread publicity for the case if Tarasov is returned [to the Soviets]. ${ }^{, 53}$ One Indian stringer for the London Daily Express, Prakash Chandra, added weight to the notion that New Delhi was actively obstructing journalist's efforts to publicise the Tarasov case. Chandra advised British contacts that, 'he and several other correspondents have been trying to file this story [on Tarasov] since early December but have been frustrated by censorship.' The New York Times' correspondent in India, Tom Brady, who had managed to circumvent the media embargo and report on the defection saga, was threatened with deportation by the Indian government. ${ }^{54}$

To the MEA's irritation, as the ponderous wheels of Indian justice ground slowly on, IRD officers worked closely with American colleagues to stimulate media coverage of the Tarasov case. During early January, the IRD reassured US officials that Reuters and the BBC had both been drafted to shine a spotlight on Tarasov's plight. Inside the subcontinent, British propagandists quietly channeled information on the Soviet defector to the Indian press. The IRD's undercover officer in New Delhi, Peter Joy, informed Whitehall that a number of Indian newspapers, including the Kolkata Current, had 'made good use of our [IRD] material.' 55 'Press publicity [in] this case is progressively increasing,' the IRD noted with satisfaction and, with British encouragement, was primed to expand further unless New Delhi changed course and facilitated Tarasov's passage to the West. ${ }^{56}$ At one point, the IRD tipped off the local press that Anton Fedoseev, cultural attaché of the Soviet embassy, and someone who had played a prominent part in the extradition case, was an officer in the GRU. ${ }^{57}$

By the end of February, in an effort to bring the Tarasov episode to a close, the Indian government appointed a special magistrate, N. L. Bakkar, to oversee the case. Its denouement played out in a small, dingy court room in New Delhi, close to the national parliament. After a month of additional testimony, and four long months since Tarasov had jumped ship, Bakkar confounded expectations, and dismissed all 
charges leveled by the Soviets against the defector, who was promptly spirited out of the country by American officials. In delivering a damning verdict, Bakkar undoubtedly went further in condemning Soviet actions than his own government would have wished. Soviet officials, the magistrate concluded, had 'manufactured evidence' against Tarasov, had failed to produce credible witnesses, and had concocted a case that was 'wholly inadequate and rife with contradictions' ${ }^{58}$ The disgruntled Soviets immediately lodged an appeal against Bakkar's ruling. Curiously, the appeal was heard by Chief Justice Donald Falshaw, a former British colonial official who had stayed on in the subcontinent following Indian independence. What faith, if any, the Soviets retained in British administered Indian justice remains unclear. Falshaw dismissed the Soviet appeal in under an hour, and reaffirmed Tarasov's right of asylum. ${ }^{59}$

To the Indian government's discomfort, the domestic and global media represented the outcome of the Tarasov affair as a zero-sum game, which the Soviets had lost. On 30 March, Prem Bhatia, the influential and anglophile Indian civil servant-turnedjournalist, pronounced in the Guardian that 'a cold war ended today between the Russian and American Embassies over a Russian who wanted to live in the West. The Americans seem to have won.' ${ }^{60}$ Two days later, Kolkata's Statesman, a newspaper that enjoyed a reputation for fiercely independent reporting and outspoken criticism of illiberal government policies, roundly condemned 'Socialist legality' in an editorial entitled 'The Ways of Justice'. The Tarasov case had, the newspaper informed its readership, accentuated fundamental differences between India's appreciation of individual freedoms and the absence of rights and justice behind the Iron Curtain, 'a grim reality of which there have been many reminders in recent years. ${ }^{61}$ The doyen of the national press, the Times of India, which was generally more accommodating of Indian governments, went further still, declaring that the 'shocking features' of the Tarasov case suggested that 'even after Mr. Khrushchev's much publicised deStalinisation campaign... the Soviet authorities are still not able to distinguish between prosecution and persecution.' Taking a thinly veiled swipe at the MEA, India's oldest daily suggested that satisfaction at Tarasov's acquittal, 'will be shared by all who believe that justice is not a matter than can be subordinated to political expediency. ${ }^{, 62}$

Western policymakers harboured a deep anxiety at the scale and impact of communist propaganda carried by the India press. ${ }^{63}$ Frequent complaints were voiced to Indian governments by London and Washington over the pernicious political influence wielded by a string of Moscow-sponsored Indian publications, such as Blitz, Patriot, Link, Mainstream, and New Age. ${ }^{64}$ In the Tarasov case, however, Western propagandists, such as the IRD, proved equally willing and adept at working through, and often in concert with, sympathetic sections of the Indian media to leverage the issue of Cold War asylum and undermine Communism inside and outside the subcontinent. If anything, the Tarasov episode offers evidence of a capacity of the part of India's judiciary, and mainstream press, to resist the imposition of political pressure and assert their independence. To the MEA's chagrin, subsequent efforts by Indian governments to insulate their relations with the Soviet Union from the impact of Cold War defections would prove to be equally ineffectual in the face of determined opposition from a familiar combination of internal and external forces. 


\section{'The most sensational defector that the United States has ever attracted': Svetlana Stalin heads West}

As the 1960s progressed, the challenges that incidents of Cold War asylum presented to the Indian government multiplied. Notably, the defection of Svetlana Alliluyeva in New Delhi, in March 1967, sparked a diplomatic uproar that tested India's relations with the West and the Soviet Union. Barely a year earlier, Lal Bahadur Shastri, who had assumed the Indian premiership on Nehru's death, in May 1964, suffered a fatal heart attack in the Soviet city of Tashkent. Shastri had been in the USSR to sign a Moscow-sponsored peace treaty with Pakistan, following an outbreak of IndoPakistani hostilities. Nehru's daughter, Indira Gandhi, was subsequently co-opted by Congress Party leaders to serve as India's third prime minister. In New Delhi, troubled British officials soon began referring to the emergence of a 'Gandhi factor' in India's international relations. More precisely, India's leader was suspected of having acquired a considerable 'chip on the shoulder' when it came to the West. Under the direction of the left-leaning Gandhi, India's diplomatic, economic, and military ties with the Soviet Union flourished. Dispirited by diminishing Western influence in India, John Freeman, Britain's High Commissioner, advocated, 'leav[ing] it to the Russians to make the running [in India], in the hope of gradually recovering our [Western] influence and eventually making a comeback later. ${ }^{65}$

Shifts in India's political landscape provided a strong incentive for Gandhi to tack to the left, and build bridges with Communists, both foreign and domestic. Popular discontent with economic mismanagement by successive Congress governments that manifested in failures to tackle rampant corruption, youth unemployment, and food shortages, weakened Gandhi's grip on power. ${ }^{66}$ National elections, held at the beginning of 1967, saw the Indian leader's parliamentary majority slashed. In the states of Bengal in eastern India, and Kerala, in the west of the country, electorates returned communist governments. Unease over Gandhi's leadership festered amongst conservative elements within her own party, and prompted a political rupture in the Congress that left the Indian premier reliant on support from the Moscow-sponsored wing of the Communist Party of India (CPI). For much of the next two decades, the 'world's largest democracy' was to be governed by a leader predisposed, both personally and politically, to exhibiting a marked circumspection in dealing with Britain and the United States. In the context of the covert Cold War this, as one former CIA officer recalled sardonically, meant that 'CIA agents . . . were to be found according to Madame Gandhi, beneath every charpoy and behind every neem tree. ${ }^{67}$

It was against this backdrop, that the Alliluyeva drama unfolded early in the evening of 6 March. Taking advantage of the distraction provided by two receptions inside the Russian embassy, one of which, appropriately enough, was celebrating Soviet 'Women's Day', a neatly dressed woman carrying a small suitcase slipped quietly into the streets of India's capital. Her destination was the United States' chancery building. On arrival, speaking in good but heavily accented English, Alliluyeva informed the marine guard on duty that she was a Russian citizen, and wished to see an embassy officer. Having been shown to the office of the US deputy chief of mission, Svetlana Alliluyeva confirmed to stunned American officials that she was the daughter of Joseph Stalin, and his second wife, Nadezhda Alliluyeva. ${ }^{68}$ As the London Economist observed, Alliluyeva was nothing less than 'the most sensational defector that the United States has ever attracted.' Reflecting on the conundrum that Stalin's daughter had presented to the American, Soviet, and Indian governments, the 
Economist added presciently that Alliluyeva constituted a surprise package that is plainly marked "Handle with care", ${ }^{69}$

Alliluyeva was the common law wife of an Indian communist, Brajesh Singh, who she met while working at a publishing house in Moscow. She had travelled to India following Singh's death to scatter his ashes into the river Ganges. Claiming to have become disillusioned with communism, Alliluyeva asked the Soviet ambassador, Ivan Benediktov, for leave to remain in India. The request was refused and, under orders to return to home, Alliluyeva decided to defect. Reasoning that it would be only a matter of hours before the Soviets discovered that Alliluyeva was missing, America's ambassador, Chester Bowles, sent a flash cable to Washington. In it, the ambassador informed the State Department that 'unless advised to the contrary' he would place Alliluyeva on a commercial flight leaving New Delhi for Rome later that evening. Having previously served as Under Secretary of State in Washington, Bowles experience told him, correctly, as it transpired, that the Washington bureaucracy was unlikely to react with sufficient speed to countermand his decision. Shortly after midnight, Alliluyeva was issued with an American B-2 tourist visa, bundled into an embassy car, and driven to Palam airport in the company of a CIA officer, Robert Rayle. Following a moment of high tension when her flight was delayed for ninety minutes due to a mechanical fault, at $2.45 \mathrm{am}$, on 7 March, Svetlana Alliluyeva departed from India and flew into political exile.

Bowles decision to facilitate Alliluyeva's defection was motivated by several factors. Denying her assistance and directing Alliluyeva back to the Soviet embassy was rejected by the ambassador as, 'completely contrary to our [US] national tradition.' The option of exfiltrating Stalin's daughter from India was deemed to involve, 'unacceptable and unnecessary risks.' It was preferable, Bowles concluded, to openly and legally put Alliluyeva on a commercial flight to the West. ${ }^{70}$ The fact that Alliluyeva's Soviet and Indian documentation was in order, and that she could be demonstrated to have departed from India of her own volition, provided some protection against charges 'of another CIA plot and against the accusation of kidnapping her [Alliluyeva] against her will.' Moreover, the ambassador rationalized that were it to become known that the American government had turned its back on, 'an appeal for assistance from the daughter of Joseph Stalin, the public outcry in the United States and elsewhere would have been overwhelming.' Equally, given the legal uncertainty surrounding political asylum, keeping Alliluyeva inside the US embassy compound risked provoking a prolonged and unwelcome diplomatic standoff. ${ }^{71}$

Early optimism voiced by Bowles that his embassy had successfully pulled off a 'ticklish' operation, proved to be premature. ${ }^{72}$ On 8 March, India's foreign secretary, Chandra Shekhar (C. S.) Jha, informed the ambassador that the Soviet Embassy was 'extremely upset' and had 'stated to Indian officials that American secret agents abducted her [Alliluyeva] from India by force. ${ }^{73}$ Coming in the wake of recent failures in the Soviet Soyuz space programme, Alliluyeva's defection threatened to tarnish Moscow's long-planned celebrations to mark the fiftieth anniversary of the Soviet revolution. One Indian newspaper noted that thousands of books, stage plays, exhibitions, lectures, and press articles were already 'being churned out in an unending stream by the official [Soviet] propaganda machine. ${ }^{74}$ The Soviets made clear their displeasure with Bowles by breaking off all contact with US officials in India. A moment of light relief amidst the diplomatic turmoil occurred a week after Alliluyeva departure, when Bowles bumped into Benediktov at a social function. The scowling Soviet ambassador taunted Bowles by asking if anyone calling at his 
embassy would be issued with a visa and a ticket to America? Quick as a shot, a smiling Bowles replied, 'For you, we will.' At which point, Benediktov dissolved into fits of laughter. ${ }^{75}$

The Indian government continued to be much less amused by Alliluyeva's defection. On 9 March, the MEA served the US embassy with a formal note of protest. The note complained that Bowles's decision to act, 'in such haste, without giving any inkling to the Ministry of such impending action, is a source of serious embarrassment to the Government of India in their relations with the Soviet Union and the United States.' The MEA expressed particular concern that the Alliluyeva affair could adversely impact the 'close and friendly relations with the Soviet Union' that the Indian government 'greatly value'. Ending with a flourish of indignation, the Indian government's admonition underlined that it could not but, 'regret this action of the US Embassy which may put in jeopardy relations between India and the Soviet Union and may have serious repercussions on Indo-US relations. ${ }^{76}$

Bowles was sufficiently disturbed by the MEA's strident tone to fire off a mollifying letter to Jha. In his palliative, the ambassador disclosed that Alliluyeva had threatened to take her case to the world's press and appeal directly to the people of India and the United States were her request for asylum denied. In the circumstances, the ambassador suggested, he had been left with little choice but, 'to give her a visa to the United States and help her on her way.' Attempting to turn the tables on his Indian hosts, Bowles presented his action as motivated primarily by a desire, 'to avoid putting the Indian government in an embarrassing position' and prevent India, the United States, and the Soviet Union from becoming embroiled in 'a legalistic and contentious public controversy.' Bowles also hinted that India's role in the Alliluyeva story was more complicated than publicly acknowledged. Specifically, the ambassador stated that Alliluyeva, whose deceased husband's nephew, Dinesh Singh, was minister for state at the MEA, claimed to have approached the Indian government for asylum. Dinesh Singh and colleagues at the MEA had, Alliluyeva informed the US embassy, indicated that India would take no action on the matter of asylum that ran contrary to the wishes of the USSR. Far better given this state of affairs, Bowles volunteered, for the Indian government to have been presented with a fait accompli by the Americans. ${ }^{77}$

It was not only the Indians that were keen to keep the Soviets on side. The State Department, too, had no desire to see such a high-profile defection dislocate wider US-Soviet relations. The importance of securing Soviet goodwill on matters ranging from Vietnam and the Middle East, to arms control and consular conventions, ranked far higher on President Lyndon Johnson's list of priorities than Soviet apostates, no matter how prominent. Undersecretary of State Foy Kohler, who had served a term as America's ambassador to the USSR, and was committed to engineering a thaw in USSoviet relations, reacted with fury to the news of Alliluyeva's defection. 'Tell them [Bowles' staff] to throw that woman out of the embassy,' Kohler had raged, 'Don't give her any help at all. ${ }^{78}$ In an effort to remove some of the political heat from the Alliluyeva affair by denying it the oxygen of publicity, the Johnson administration offered little public comment. The British were advised by American colleagues that the defection was, 'being handled very restrictively indeed within the [Johnson] Administration and that only three to four people in the State Department and White House are au courant. ${ }^{79}$ In New Delhi, the US embassy was, 'instructed not to talk to people about the [Alliluyeva] episode. ${ }^{80}$

Encouragingly for Washington, signals coming out of the Soviet Union indicated that Moscow was equally keen to downplay events. On 21 March, in a meeting with 
Indian diplomats, the Soviet deputy foreign minister, Nikolay Firyubin, adopted a 'relatively mild' attitude to Alliluyeva's defection, at one stage making light of the fact that, by neglecting to confiscate Alliluyeva's passport, Benediktov had unwittingly facilitated her defection. Relieved Indian officials indicated to American colleagues that the differences between Benediktov's aggressive response to the Alliluyeva affair, and Firyubin's more relaxed reaction, appeared reflective of the Soviet ambassador's personal insecurities rather than official Soviet thinking. ${ }^{81}$ Such thinking appeared justified when, in April, Benediktov was demoted and transferred to Yugoslavia.

Nevertheless, the Soviets did indicate to the American embassy in Moscow that their forbearance would last only so long as the United States continued to display sensitivity to the embarrassing position in which the USSR had been placed by Alliluyeva's actions. Notably, a KGB officer warned American counterparts that were Alliluyeva granted permanent asylum in the US, as opposed to another Western country, the Soviet intelligence agency would conduct a disinformation campaign, complete with forged documents, detailing how the CIA had coerced Stalin's daughter into defecting. ${ }^{82}$ With Indian officials also maintaining a stony public silence on Alliluyeva, 'except to announce that India had nothing to do [with her defection]', it appeared that a dangerous diplomatic squall might blow over.

Events back in in the United States, however, cast a spotlight on the activities of the CIA that, in turn, reignited concern in India over the Agency's role in the Alliluyeva affair. Specifically, the American west-coast magazine, Ramparts, published an exposé detailing the CIA's secret financial relationships with a number of international educational institutions and cultural bodies, some of which operated in the subcontinent. British officials in India rued that the Alliluyeva episode had coalesced with the Ramparts story to spark, 'a renewal of public interest in the actual and conjectural activities of the C.I.A. in India.' In the Lok Sabha, India's lower house of parliament, Communist MP's accused government ministers of being on CIA's payroll. In response, Congress parliamentarians levelled counter-allegations that members of the Opposition had been unwitting recipients of CIA funds. ${ }^{83}$ In the midst of a maelstrom of suspicion, rumour, and paranoia surrounding the CIA, Bowles was summoned to the MEA to account for a fresh accusation that the Agency had orchestrated Alliluyeva's defection. The Soviet embassy, Indian officials informed Bowles, claimed to have received, 'information from U.S. sources that there had been correspondence between U.S. and Indian officials and that this had indicated there was some kind of Indo-American complicity [in Alliluyeva's defection].' An indignant Bowles rebutted the Soviet charge. Whether the US had, or had not, enticed Alliluyeva to defect, dispirited MEA officers responded, was a moot point. The Soviet embassy, the American ambassador was informed, 'simply cannot believe that Indian officials did not know that Svetlana was leaving when she did. They have therefore convinced themselves of Indian duplicity. ${ }^{24}$

Speculating on a hardening in Moscow's attitude to Alliluyeva's defection, Triloki Nath Kaul, secretary at the Ministry of External Affairs, suggested that that Soviet premier, Alexei Kosygin, had come under scrutiny in the Kremlin for his role in Alliluyeva's flight. At the time, Kosygin was in the midst of a power struggle with rivals in the Soviet leadership, including the general secretary of the communist party, Leonid Brezhnev, and chairman of the presidium, Nikolai Podgorny. It had been Kosygin, Kaul noted who 'had personally permitted Svetlana to come to India against the advice of some other members of the politburo. ${ }^{85}$ To its consternation, the Indian government found itself at the centre of a tussle between competing factions within 
the Soviet government. Some in the politburo and Soviet foreign ministry, such as Firyubin, sought to play down India's role in the Alliluyeva incident. Other Soviet officials, most notably Benediktov and Kosygin, had good reason to do precisely the opposite. Complaining that it was 'absurd' for the Soviets to persist in 'accusing the Indian government of having worked in cahoots with United States Embassy', the MEA nonetheless came under 'heavy' pressure to act on purported US interference in India's internal affairs. ${ }^{86}$

Toward the end of March, the Soviet charges of Indo-US complicity in the Alliluyeva case began to strain Indian patience. With celebrations to mark the twentieth anniversary of the establishment of diplomatic relations between India and the USSR looming, British officials observed a lack of mutual 'sympathy' between Moscow and New Delhi. One Indian diplomat confided to British colleagues that he had been treated 'very frigidly' on a recent visit to the Soviet capital as a consequence of the Alliluyeva incident. ${ }^{87}$ Meanwhile, Andrei Gromyko, the Soviet foreign minister, adopted an unusually firm line with Indian interlocuters on the sensitive issue of nuclear non-proliferation. ${ }^{88}$ Calling the Soviet deputy chief mission, Smirnov, into the MEA, R. Jaipal, India's joint secretary for external affairs, reiterated testily that the Indian government had provided Moscow with an official undertaking that it had played no part in Alliluyeva's defection. Should the Soviet government persist in discounting India's assurances, Jaipal stated curtly, there would no longer 'be [a] proper basis for the development of future relations between the two countries.' Appraised of his encounter with Smirnov by an exercised Jaipal, Bowles advised Washington that, 'It is clear that Indians are starting to get their dander up over continued Soviet pressure. 89

Back in Whitehall, Sir Paul Gore-Booth, permanent under-secretary of state at the Foreign Office, hatched plans to exploit the Alliluyeva defection. Gore-Booth praised the manner in which American colleagues had taken the "very wise step of not giving the defection what might be called "routine exploitation"" and unduly ruffling Soviet feathers. However, the veteran diplomat, who served as British High Commissioner in India in the early 1960s, suggested that there were "ways in which, so to speak, the free countries should "exploit this non-exploitation"”. Arguing that the Alliluyeva defection 'was of quite a different order' from anything the West had seen in recent memory, Gore-Booth underscored that it had been rationalised in humanitarian rather than ideological terms. By encouraging and amplifying press comment that echoed Alliuyeva's emphasis on Soviet constraints upon individual liberties, the inequities of the communist system could be illuminated without London being accused of crude political point scoring. 'This [universal human rights] may not be a new doctrine,' Gore-Booth reasoned, 'but its relaunching by the daughter of Stalin, in the fiftieth year of the Communist Revolution in Russia, is immensely important. ${ }^{90}$

The Foreign Office quickly set about putting Gore-Booth's idea into action. Whitehall's strategy was to stimulate its contacts in the press 'not to play this [Alliluyeva's defection] as a cold-war operation', but to stress the 'absence of personal and cultural freedom' in the Soviet Union that Stalin's daughter had referenced as fundamental to her decision to defect. Alliluyeva had, the Foreign Office noted, criticised Moscow's decisions to proscribe Boris Pasternak's novel, Doctor Zhivago, and to sentence the writers Andrei Sinyavsky and Yuli Daniel to hard labour for publishing satirical works critical of the Soviet regime. ${ }^{91}$ In India, the IRD worked covertly with one of its contacts, Gopal Mittal, owner of the National Academy Publishing House in New Delhi, to issue an article entitled, 'Unending Soviet War on Intellectuals.' Reproduced across northern India in English, Urdu, 
Hindi, and Punjabi editions, the article observed that by persecuting its intellectuals and assaulting fundamental human rights, Moscow was 'slapping public opinion, at home and abroad, in the face. ${ }^{92}$ Meanwhile, the Sunday Times, which intended to serialise an autobiographical manuscript that Alliluyeva had persuaded T. N. Kaul to smuggle out of Moscow, were encouraged by British officials to keep the story alive and on the newspapers front pages. ${ }^{93}$ Commentators in the press speculated that the Kremlin would 'undoubtedly' be worried by the impact that an illicitly distributed book written by Alliluyeva would have inside the Soviet Union. The effect, one Indian journalist suggested, could be 'comparable to Khrushchev's "secret speech", the publication of which by the US State Department in 1956 had helped to ferment unrest in Poland and Hungary, and contributed to 'other political troubles which beset the Soviet empire. 94

Utilising Alliluyeva to throw the Soviets off-balance appealed to the IRD. In September 1967, a proposal from the department to have Shirley Williams, the minister of state for education and science, review Alliluyeva' memoir on the flagship BBC Radio 4 programme, Women's Hour, was rejected by the Foreign Office 'because of the extreme sensitivity of Soviet Government on this matter." had more success in selling the merits of unattributable propagandising, or activity that could not easily be traced back to Whitehall. Through its covert network in India, the IRD arranged to distribute copies of Alliluyeva's book, Only One Year, to sympathetic Indian politicians and journalists. The book, which America's propaganda agents in South Asia had declined to circulate for fear of antagonising Moscow, was, IRD officers crowed, 'practically unobtainable in India...as the Indians, at Soviet insistence...were holding up imports." ${ }^{96}$ Although more active than the American government in working behind the scenes to keep media interest in Alliluyeva alive, the British congratulated themselves on remaining largely under the Soviet radar, and avoiding Moscow's ire.

In contrast, in the United States, the Johnson administration faced welcome press scrutiny for its handling of the Alliluyeva case. In an article entitled, "Svetlana Lost or Found?', the conservative National Review chided Johnson for ignoring the fact that, '...Svetlana Alliluyeva is playing out a momentous role in history...[while Washington had decreed that] Svetlana's defection must be neutralized, drained of its large historical meaning...so that the image of an increasingly benign Communist Russia may be permitted to stand undisturbed. ${ }^{97}$ At the same time, the Soviet press lambasted 'ruling-circles' in Washington for indulging in 'provocations of the highest level' that were designed to derail Soviet-American détente. ${ }^{98}$ A succession of press conferences, media interviews, and public appearances made by Alliluyeva in the United States, coupled with the revelation that a tell-all memoir would shortly be rolling off American presses, shattered Soviet complacency that an accommodation could be reached with the US government to minimise political fallout from the defection. The fact that George Kennan, a former US ambassador to the Soviet Union, whom Stalin had declared persona non grata, and who had provided the intellectual rationale for the policy of Cold War containment, was known to be assisting Alliluyeva with her book, did little to assuage Moscow's sense of American bad faith. On 27 May, Pravda accused the CIA and United States Information Service of exploiting 'the Svetlana affair...[to orchestrate] a massive anti-Soviet propaganda campaign.' 'In short,' the official newspaper of the Soviet communist party declared, 'Washington is stooping to use anything...[in] making use of Soviet citizen S. Allelueva [sic].' 99 
In an ironic twist, after two decades living in the United States and the United Kingdom, Alliluyeva eventually returned to Russia. In late 1984, the year in which year George Orwell had set his dystopian vision of a future totalitarian state, Svetlana Stalin came home. Anticipating a dose of their own propaganda medicine, one Western commentator, who had known Alliluyeva well, observed ruefully that, 'Naturally, she'll be expected and indeed required [in the Soviet Union] to make violently abusive attacks on America and Britain. ${ }^{100}$ The game of Cold War asylum, it seemed, had turned full circle. In more immediate terms, the Svetlana Alliluyeva affair had a profound influence on the manner in which the Indian government approached the defection of another Soviet citizen, Aziz Saltimovitch Ulug-Zade, in December 1967. With the political fallout from Alliluyeva's decision to use New Delhi as a staging-post to the West still reverberating through the corridors of India's Ministry of External Affairs, Indira Gandhi's government adopted a heavy-handed, legalistic, and ultimately ineffective response to the increasingly vexing issue of political asylum. In the process, the Indian government drew censure from domestic critics, and embittered its relations with the United States, the United Kingdom, and the Soviet Union.

\section{'To have three Russian defections occur in your country within three years is embarrassing...': Ulug-Zade and the Containment of Cold War Asylum}

On 21 December 1967, with newsprint barely dry on the acres of paper that India's press had devoted to Svetlana Alliliuyev's defection, New Delhi was greeted by a raft of unwelcome and sensationalist headlines in the wake of Aziz Ulug-Zade's disappearance. The Times of India's front-page pronounced dramatically, 'Soviet youth vanishes in Delhi and causes Diplomatic sensation.' The MEA, the leading Indian daily reported, had taken a 'very serious view of this incident, since it does not want India to be turned into a cold war arena by the Big Powers in their game of international espionage and psychological warfare.' Moreover, Indian government officials were said to be concerned that, coming just eight months after the Alliluyeva episode, Ulug-Zade's defection would have 'wider political repercussions' for IndoSoviet relations. ${ }^{101}$ Revealingly, the Soviet press made no mention of the Ulug-Zade case. From Moscow, Indian diplomats reported that the Soviet foreign ministry had maintained an icy silence on the matter. Instead, the Soviet ambassador in New Delhi was employed to exert maximum pressure on the Indian government to see that the latest defection incident was dealt with quickly, quietly, and to Moscow's satisfaction. ${ }^{102}$

The Soviet embassy's immediate reaction to Ulug-Zade's flight reinforced Indian anxieties that Russian tolerance on the issue of political asylum had been exhausted. Nikolai Pegov, the Soviet ambassador, stormed into the MEA and demanded that the youth leader be returned to his custody. Having rescinded Ulug-Zade's passport, Soviet officials informed Indian, American, and British counterparts that it would be considered an unfriendly act were they to facilitate his defection to the West. Under Soviet pressure, the MEA instructed Delhi's police to find Ulug-Zade, and to ensure that he remained in India until the facts surrounding his disappearance could be established. However, as Indian journalists were quick to point out, the extent to which their government could satisfy Soviet demands in respect of Ulug-Zade were limited. Under Indian law, and in accordance with international conventions on asylum, New Delhi had no authority to compel the defector to return to the Soviet Union. Having entered the country legally on a visa issued by the Indian embassy in 
Moscow, and following the cancellation of his Soviet passport, Gandhi's government was empowered only to deport Ulug-Zade to a country of his choosing. ${ }^{103}$

Soviet indignation at the latest defection to take place in India was magnified by a familiar suspicion that the CIA may have been behind the Ulug-Zade affair. Eastern bloc diplomats in New Delhi confided to Indian officials that Moscow suspected the US intelligence agency of getting even for the recent defection of an American citizen, John Discoe Smith. Before seeking political asylum behind the Iron Curtain, Smith had served as a communications clerk in the US embassy in Delhi. The Soviets subsequently arranged for a communist publishing house in India to release a salacious account of purported CIA misdeeds in South Asia, under Smith's name. ${ }^{104}$ Moreover, as the Indian Embassy in Moscow underlined to the MEA, in using the Smith 'revelations' to attack Indian right-wing politicians, Soviet propagandists over reached themselves and alienated Indian opinion. 'There was quite a lot of resentment in India of critical references of the broadcasts of the [Soviet] "Radio Peace and Progress" and the publication in the [Moscow] Literary Gazette of John Smith's article in which some distinguished Indian leaders were maligned,' Indian diplomats in the Soviet capital reported. 'It was explained to Soviet officials in Moscow that such partisan articles by Soviet publicity media were bound to affect relations between the two countries. ${ }^{105}$

Allegations of CIA interference in India's internal affairs had featured prominently in the Indian national elections that spring, and had been amplified by the Agency's association with Alliluyeva's defection. Consequently, fresh rumours of American intelligence involvement in the Ulug-Zade case were politically explosive, and spread panic inside the Indian government. ${ }^{106}$ Moreover, from an Indian perspective, other worrying echoes of the Alliluyeva case emerged. Specifically, the international press began to insinuate that Ulug-Zade had been motivated to leave the Soviet Union by a denial of freedom of expression, constraints imposed on fundamental human rights, and the 'treatment of Soviet writers and intellectuals.' The Russian defector, one newspaper emphasized pointedly, was the son of a well-known Uzbek poet. ${ }^{107}$

In part, the diplomatic frenzy sparked by the Ulug-Zade affair explains the decision taken by John Freeman to turn the Soviet teacher away when he came calling on the evening of 19 December. London's relations with India remained tense following a spat between Harold Wilson's government and New Delhi during the Indo-Pakistan war of 1965. Consequently, Freeman baulked at taking in the Soviet defector and risking the Gandhi administration's ire. Any thoughts that Freeman may have entertained about offering Ulug-Zade sanctuary were further complicated by the intervention of Nikolai Pegov. Having been alerted by companions of Ulug-Zade that he might seek sanctuary at the UK High Commission, the Soviet ambassador contacted Freeman directly and made clear that Moscow would react strongly were the British mission to harbour a Soviet citizen. ${ }^{108}$ To add to Freeman's problems, his communication links back to London were temporarily compromised. At the time, Stella Rimington, a future director-general of the British Security Service, MI5, was working as an assistant to the Service's resident Security Liaison Officer (SLO) in India. Rimington recalled how, with a defector standing on their doorstep, the SLO was unable to locate the duty cypher clerk and dispatch a request to London for instructions. It later transpired that, anticipating a quiet night at work, the cypher clerk had slipped off to be with a Sikh boyfriend, and ignored repeated telephone calls and frantic knocks on her door. ${ }^{109}$

Isolated and under pressure to act, Freeman turned to colleagues at the American embassy for advice. Although wary that the United States might be subject to a Soviet 
deception exercise designed to compromise Washington's relations with New Delhi, Chester Bowles agreed to take-in Oulug-Zade while enquires were made as to his bona fides. One senior US embassy official later recalled that, 'the British ducked and he [Oulug-Zade] wound up as a houseguest in the American Embassy residential compound... We wanted to be more forthcoming than the British so we granted him asylum while we debated [what to do]. ${ }^{110}$ Alarmed that Chester Bowles might act precipitately, as in the case of Alliluyeva, the MEA sought an assurance from the US embassy that Oulug-Zade would 'not be whisked out of the country without its knowledge.' Having been stung by political fallout from the Alliluyeva affair, the last thing that the Johnson administration wanted was a second defection crisis on its hands. Accordingly, Galen Stone, senior counsellor at the US embassy, was quick to reassure Indian government officials that Washington would ensure every 'effort was made to find a way out of this tangle without undue embarrassment to either side.' 111

A solution to the Oulug-Zade conundrum arrived from an unexpected quarter. The British, having previously spurned Oulug-Zade request from asylum, abruptly reversed course, and indicated that they were, after all, prepared to offer sanctuary to the Soviet citizen. Toward the end of December, Freeman formally advised the MEA that the British government had received, and accepted, an application for political asylum from Oulug-Zade. ${ }^{112}$ It remains uncertain what prompted London's volte-face. Short of engineering Oulug-Zade's return to the USSR, averting the media spectacle of a second Soviet defector transiting from the subcontinent to the United States within the same year would certainly have been agreeable to Moscow and New Delhi. Oulug-Zade had previously expressed a preference for relocating to the United Kingdom, and had made the British High Commission his first port of call after deciding to defect. The British reversal was, therefore, able to be couched in humanitarian terms. Whatever the reason, it seems likely that some form of deal was struck between Bowles, Freeman, Pegov and the MEA to recast the Oulug-Zade issue as something other than a direct confrontation between the US and Soviet superpowers. The effect, as undoubtedly intended, was to remove much of the political pungency from the defection.

That is not to say that the end-game of the latest Soviet defection in India passed off without incident. As frustrated officials inside the MEA worked to bring the Oulug-Zade case to a satisfactory conclusion, opponents of Gandhi's administration once again sought to score political points from the country's latest defection drama. On 22 December, during a three-hour foreign affairs debate in the Lok Sabha, Gandhi was repeatedly thrown on the defensive. Minocher Rustom 'Minoo' Masani, a leading figure in the conservative Swatantra Party, baited the Indian premier over her government's failure to confirm that Oulug-Zade would be allowed full freedom to determine his own destiny. Linking the Oulug-Zade case to a recent agreement reached by the Indian government with the Soviet news agency, Novosti, which had ties to Russia's intelligence services, Masani lambasted Gandhi's tendency to 'lean over backwards to please the Soviet Government. ${ }^{113}$ In addition, Masani arranged for an open letter of support for Oulug-Zade to be signed by prominent Indian figures, including Koka Subba Rao, a former Chief Justice of India, and G. L. Mehta, onetime Indian ambassador to the United States. The letter appealed to India's prime minister, 'on the grounds of fundamental human rights embodied in our Constitution and in the Universal Declaration of Human Rights to which India is a signatory to allow Aziz [Oulug-Zade] to go to the United Kingdom without further delay and in accordance with his choice.' Asserting that it would be a 'disgrace' to India were the Soviet defector coerced into returning home, the document warned Gandhi's 
government against 'injur[ing] India's international prestige' by succumbing to pressure from Moscow. ${ }^{114}$

The question of how best to exploit Indian criticisms of the Gandhi government's position on Oulug-Zade occupied the attention of Western propagandists and, not least, those working within the IRD. The department debated passing unattributable material to Indian contacts in the press that highlighted growing political dissent amongst Soviet youth, noted resistance to Moscow's rule within the Soviet Central Asian Republics, and repackaged elements of the Tarasov and Svetlana defections. In some quarters of the British intelligence community, Oulug-Zade's intellectual credentials apeared to offer up an excellent opportunity for publicising the suffocating cultural constraints imposed by the Soviet regime on its citizens. A senior officer of the British Security Service subsequently categorised Oulog-Zade as, 'a man of great intelligence - in fact the most intelligent defector with whom he had ever had contact.' It was Ulugzade's [sic] intellectual penetration,' MI5 concluded, 'which had made him no longer content to endure the various shame imposed on him in the Soviet Union and so led him to defect. ${ }^{\text {, }} 15$

In an Indian context, further efforts to capitalise on the theme of Soviet persecution of writers and intellectuals was, however, dismissed as unwise on two grounds. Firstly, bringing additional pressure to bear on Gandhi and her ministers, it was reasoned, risked damaging delicate bilateral relations and making the Oulug-Zade imbroglio 'harder to solve' by 'provoking those inside and outside the [Indian] Government who stand to lose most by Oulug-Zade's unwavering preference for Britain.' Secondly, Indians were doing an excellent job by themselves of holding their government to account. 'As you will doubtless have noticed from the [local] press coverage,' the resident IRD office informed London, 'the facts of the case have been sufficient both to provide a condemnation of Communism and to place the Indian authorities in a position where they would risk compromising themselves and their democratic freedoms if they had refused to accede to Oulug-Zade's wish [to resettle in the UK]. ${ }^{, 16}$ In the circumstances, the IRD was content to bide its time and delay public exploitation of Oulug-Zade's defection until after the Soviet national had departed from the subcontinent. ${ }^{117}$ As the chairman of the British Joint Intelligence Committee reasoned, while 'it would be quite normal for Mr. Ulugzade [sic] to give modest publicity to his experience...we would not want to mount an operation on his behalf. He is not our answer to Philby... \& the K.G.B. ${ }^{118}$

Indeed, as 1967 drew to a close, Indira Gandhi and her government remained under sustained pressure from domestic political opponents determined to characterise the Indian government's 'equivocal attitude' to the issue of political asylum as a fundamental 'breach of human rights.' On 27 December, addressing a press conference convened under the auspices of the Indian Committee for Cultural Freedom and the Indian Group of the Liberal International, Masani accused the MEA of inhumane and illegal behaviour in seeking to deny Oulug-Zade a 'sanctified right' to asylum in the West. The ministry of external affairs, the Indian MP imputed, 'was acting illegally to please the Soviet Government. ${ }^{119}$ Attacks from the Indian right rattled Gandhi's administration which, with limited success, attempted to recast the issue of political asylum as a problem of the United States' making. Government allies in the Communist Party warned the Indian public that Washington was utilising Soviet defectors to destabilise New Delhi's relations with Moscow. Meanwhile some of Gandhi's own MPs, such as Arjun Arora, lamented that as a consequence of American machinations, 'India was becoming a Cold War arena'. The time had come, Arora stated bluntly, to put an end to foreign powers abusing India's goodwill, and 
using the country to score cheap propaganda points at the expense of India's wider political and economic interests. ${ }^{120}$

The Oulug-Zade affair touched an especially sensitive nerve inside the MEA. As one Indian newspaper noted, the country's diplomats resented 'allow[ing] Indian soil to be used for cold war propaganda and thereby embarrass itself in its relations with other friendly [Eastern bloc] countries. ${ }^{121}$ However, as Indian lawyers deputised to advise Oulug-Zade made perfectly clear, the MEA could expect legal challenges were attempts made to return the defectors to the Soviet Union. Referencing the Tarasov case back at the beginning of the decade, Gandhi's government was reminded that the State had come off badly when the issue of defectors rights had last been placed before the judiciary. ${ }^{122}$ Still, angered by what it regarded as an abuse of freedoms prevailing in India by three Soviet defectors over the previous five-years, the MEA notified diplomatic and consular missions in the country that it did not accept their right to grant asylum. 'The Government of India do not recognize the right of...Missions to give asylum to any person or persons within their premises,' a directive drafted by the MEA's Legal and Nationality department stated bluntly. Insisting that it was 'well established international practice' that 'the affording of asylum is not within the purposes of a Diplomatic Mission', foreign diplomats were told not to grant, 'any request for asylum, or temporary shelter, or refuge.' 123

In a private discussion with Freeman, Kaul went further, and confirmed that New Delhi was examining existing legislation with a view to making the sheltering of defectors an offence under Indian law. ${ }^{124}$ British and American officials in India concluded that the MEA's threat was unenforceable, and ignored the trial balloon. In London and Washington, analysts concurred that 'the main purpose of the Indian circular was to discourage other would-be defectors from using India as their take-off point.' The terms of the 1961 Vienna Convention on Diplomatic Relations, it was noted, legitimized asylum on humanitarian grounds. Accordingly, British diplomats in New Delhi were instructed, 'not in any way concede to the Indian authorities that asylum may not be granted on this ground.' Although 'anxious to promote friendly relations' with India, and 'willing to accommodate the Indian Government as far as possible', the British stopped short of publicly qualifying their support for Cold War asylum. ${ }^{125}$ Following the State Department's lead, and after 'a considerable amount of inter-departmental consultation', Whitehall disregarded the MEA's approach. ${ }^{126}$ In fact, as Indira Gandhi was forced to concede on 14 February during a debate in the Lok Sabha, the MEA failed to receive a single formal reply to its circular on asylum from any foreign mission in New Delhi. ${ }^{127}$ In response to the noise generated by the Indian government on political asylum, the international diplomatic community elected to turn a collective deaf ear.

\section{Conclusion}

Recovering the history of political asylum within the hitherto elided context of the developing world illuminates the extent to which leading non-aligned states, such as India, were compelled to assume prominent roles in the high drama of defection as the Cold War spread outwards from Europe and into Africa and Asia. Significantly, the Indian government's engagement with the thorny diplomatic problem posed by political asylum exposed the existence of deep fault-lines between Indian domestic sentiment, which broadly favoured a liberal and compassionate policy on asylum, and New Delhi's conviction that the nation's wider interests were best served by an uncompromising and legalistic response to political refugees originating from the 
Eastern bloc. Indian officials invariably found themselves squeezed by seemingly contradictory demands to defend New Delhi's post-independence commitments to freedom of political expression, individual liberty, and universal human rights while, simultaneously, pursuing national security interests that hinged on the maintenance of constructive relationships with the superpowers.

For the remainder of the Cold War, Soviet military and economic ties to India held firm, in part as a consequence of crisis in Indo-US relations occasioned by the Nixon administration's tilt to Pakistan during the East Pakistan/Bangladesh crisis of 1971. At the time, one of Indira Gandhi's closest foreign policy advisors, P. N. Haksar, informed the Indian premier, 'I personally believe that our relations with the Soviet Union are of cardinal importance and they are going to acquire increasing importance in the years to come. ${ }^{128}$ The use of India by Eastern bloc defectors as a convenient route to the West continued, however, to inject tension into bilateral relations between India and the Soviet Union. In February 1970, a year prior to the conclusion of an Indo-Soviet Treaty of Friendship and Cooperation, a fourth Soviet citizen, Youri Bezemenov, slipped quietly out of the Indian capital and into political exile. An official posted to the USSR's Information Centre, Bezemenov had, appropriately enough, spent his last evening in the subcontinent watching an American film in a Connaught Place cinema, before disappearing into the Indian night. ${ }^{129}$ By 1972, the Times of India had become almost blasé in reporting the latest Soviet national to abscond on Indian soil. Informing its readership that Mr. A. V. Tereshkov, a Russian engineer working at the Bokaro steel plant, in the east of the country, had disappeared with his family, the Times reflected ruefully that a nationwide alert and stringent checks placed on airports and border posts had failed to turn up the Russians. 'It is believed', the newspaper added, 'that they [the Tereshkov family] had already left India with the help of a foreign mission.' 130

Indian domestic politics, however, ensured that the issue of political asylum remained a choleric component of North-South dialogue. In June 1975, having come under investigation for electoral malpractice, and with protestors having taken to India's streets in almost equal numbers both to support and denounce her government, Indira Gandhi declared a national state of emergency, suspended civil liberties, censured the press, and jailed political opponents. The large-scale and arbitrary detention of opposition politicians and activists prompted Amnesty International to categorise the Indian government's action as, 'perhaps the most significant event of the year in terms of human rights in Asia. ${ }^{131}$ The British and American governments found themselves inundated with applications for political asylum from Indian critics of Gandhi's government who had managed to evade arrest. In turn, the sympathetic line taken in London and Washington to requests from Indian citizens for political asylum garnered New Delhi disapprobation. ${ }^{132}$

Considerable scholarship has been expended on interrogating defection in an EastWest framework, but more expansive geo-political considerations of the issue remain opaque and are much less well understood. If the Indian government's campaign to inhibit Cold War defections in the subcontinent did not yield tangible results in the long 1960s, it nevertheless represented a significant event. The MEA's involvement provides evidence of a democratic government reinterpreting international law to suit diplomatic exigencies; and, taken together with recent disclosures of ubiquitous and active covert foreign intelligence operations in India, it reinforces the scale of the Cold War's impact on South Asia. Furthermore, the episode also enhances understanding of how Britain, the United States, the Soviet Union, and India approached political asylum in a non-European context. Not least, the considerable 
costs that Indian governments confronted in respect of East-West defections, both in domestic political terms and in the context of broader national security, can be seen to have contributed to the emergence within Indira Gandhi's government of a conviction that non-alignment had come to outlive its utility as an instrument of international relations.

The transformation of India's capital city into an Asian Berlin at the height of the Cold War was always going to be problematic for a nascent non-aligned nation burdened with a colonial history of political oppression and human rights abuses. Striving to balance national security concerns against prevailing domestic sentiment resulted in a measure of hedging and obfuscation on the part of Indian governments. Once enmeshed in the politics of Cold War asylum, New Delhi sought to actively discourage and disrupt defections on Indian soil while, at the same time, working assiduously to minimise any adverse impact on its relationship with Moscow. In the process, Indian officials floundered in the face of competing local pressures, domestic political rivalries, and diplomatic exigencies. The politics of Cold War asylum presented a problem to which Indian governments could find no satisfactory solution.

\footnotetext{
Notes

${ }^{1}$ Joy to Barclay, 8 May 1964, FO 1110/182; 'India', 5 Dec. 1967, FCO 95/290. Unless otherwise cited, all archival references are to the National Archives, London.

${ }^{2}$ S. Mulgaokar, 'The Right of Asylum', Weekend Review, (2, 5), 6 Jan. 1968, 3-4.

${ }^{3}$ Cole to Hunt, 'Political Asylum in India', 5 Jan. 1968, FCO 37/62.

${ }^{4}$ Mulgaokar, 'Right of Asylum', 3-4.

${ }^{5}$ The Times of India, 21 Dec.1967, 1.

${ }^{6}$ A. R. Wic, 'The Ulug-Zade affair', Weekend Review (2, 5), 6 Jan. 1968, 6-7.

${ }^{7}$ See, for example, Andrew, Defence of the Realm; Jeffreys-Jones, Cloak and Dollar; and Prados, Safe for Democracy. Some works have sought to engage with the intelligence Cold War from a broader global perspective, notably, Davies and Gustafson (eds.), Intelligence Elsewhere.

${ }^{8}$ Scholarship addressing India's Cold War relations has largely ignored the issue of political asylum. The otherwise authoritative account of US-Indian relations produced by former American diplomat, Denis Kux, avoids the issue. See, Kux, India and the United States. Howard Schaffer, who served in the US Embassy in India in the 1960s, provides a brief account of the Alliluyeva episode in Chester Bowles. Rosemary Sullivan offers up an insightful view of Alliluyeva's defection from the Soviet citizen's perspective in, Stalin's Daughter. See also, Svetlana Alliluyeva's own account of her defection in, Only One Year.

${ }^{9}$ See, Westad, The Cold War; Chamberlin, Cold War's Killing Fields; and, McMahon (ed.), Cold War in the Third World.

${ }^{10}$ Mišković et al., Non-Aligned Movement; Abraham, 'From Bandung to NAM'; Lee (ed)., Making a World After Empire. See also, Lewis and Stolte (eds.), 'Other Bandungs'.

${ }^{11}$ Lüthi, 'The non-aligned' in Mišković et al., Non-Aligned Movement, 97.

${ }^{12}$ See, for example, Carruthers, Cold War Captives; Volodarsky, Stalin's Agent; Knight, How the Cold War Began. On the 'Cambridge Five' see, Knightley, Philby; Macintyre, Spy Amongst Friends; and Lownie, Stalin's Englishman.

${ }^{13}$ For instance, Cherkashin, Spy Handler; Woodward, The Secret Wars of CIA; and Crile, Charlie Wilson's War.

${ }^{14}$ Krasnov, Soviet Defectors, 116.

${ }^{15}$ Le Carrè, Tinker Tailor, Soldier Spy.

${ }^{16}$ Aldrich, 'Policing the Past', 1.
} 
${ }^{17}$ Official histories of British intelligence authored by the late Keith Jeffrey and Christopher Andrew have cast some light on the post-war operations of SIS and MI5. See, Jeffrey, MI6, and Andrew, Defence of the Realm.

${ }^{18}$ Recent scholarship has examined facets of the secret intelligence dimension of South Asia's Cold War. However, this work has not yet touched upon defection or political asylum as a component of intelligence activity. See, for, example: Pullin, 'Congress for Cultural Freedom'; McGarr, 'Quiet Americans'.

${ }^{19}$ See, Kaul's work in Reporting the Raj; Media and the British Empire; and Media and the Imperial Experience. Also, Finkelstein and Peers (eds.), Negotiating India; and. Codell (ed.), Imperial CoHistories.

${ }^{20}$ See, for example, Baghavan's emphasis on the centrality of human rights to early Indian foreign policymaking, in The Peacemakers.

${ }^{21}$ Balachandran, National Security and Intelligence, 112.

${ }^{22}$ See, Den Heijer. 'Diplomatic Asylum'; UN Secretary-General, 'Survey of International Law'; and, International Law Commission, 'Summaries of the Work'.

23 'Draft declaration on right of asylum', 14 May 1959, Ministry of External Affairs [MEA], United Nations-I, File No.151(109)-UNI, National Archives of India, New Delhi [NAI].

${ }^{24}$ Nehru to Pant, 11 Jul. 1958, Subject File 6, Apa B. Pant Papers, Nehru Memorial Museum and Library, New Delhi [NMML]; 'Chinese Intentions against India', Joint Intelligence Committee (JIC) report, 22 Nov. 1962, CAB 158/47. For a wider discussion of the Cold War politics associated with Chinese asylum seekers, see, Jacobs, 'Exile Island'.

${ }^{25}$ Conversation between R. K. Nehru and Chou En-lai, 21 Apr. 1960, Subject File 26, NMML. See also, Guyot-Réchard, Shadow States, 185; and, Wasif Khan, Muslim, Trader, Nomad, Spy.

${ }^{26}$ The evolution of Indo-U.S. relations under Eisenhower and Kennedy has received significant scholarly attention. See, for example, McGarr, Cold War in South Asia; McMahon, Cold War on the Periphery; and Dauer, North-South Mind.

${ }^{27}$ Blake, No Other Choice. 167.

${ }^{28}$ Mary Seymour Olmsted, Oral History, 8 Apr. 1992, Foreign Affairs Oral History Project, Library of Congress, Washington D.C. INTERNET, http://memory.loc.gov/ammem/collections/diplomacy/ (accessed 7 Feb. 2013).

${ }^{29}$ Conboy and Morrison, CIA's Secret War, and Knaus, Orphans of the Cold War.

${ }^{30}$ Andrew and Mitrokhin, The Mitrokhin Archive II, 9-10 and 312-14.

${ }^{31}$ Kalugin, Spymaster, 141.

${ }^{32}$ Tromly, 'Ambivalent Heroes', 1.

${ }^{33}$ See, for example, 'Working Party on Russian and Satellite Defectors and Refugees', CAB 301/136.

${ }^{34}$ Donaldson (MOD), 4 Aug. 1950, CAB 301/136. See, also, Richelson, US Intelligence Community, 328-32.

${ }^{35}$ Macmillan's distaste for the secret world's work is documented in, amongst others, Horne, Macmillan, 457, and. Thorpe, Supermac, 310.

${ }^{36}$ Meeting between Churchill, Nutting, Rennie and Kirkpatrick, 1 May 1954, PREM 11/773. A fictional rendering of SIS's proclivity for using the United States to extract propaganda value from Soviet defectors, that bears more than a passing resemblance to the Khokhlov case, appears in Le Carrè's, Secret Pilgrim, 152.

37 'Petrov Defection Policy', The Royal Commission on Espionage, 1954-55, Series Number A4940, C926, National Archives of Australia, Canberra. See also, Petrov, Empire of Fear.

${ }^{38}$ Cheney to Rumsfeld, 'Solzhenitsyn', 8 Jul. 1975, Box 10, folder "Solzhenitsyn, Alexander", Richard

B. Cheney Files, Gerald R. Ford Presidential Library (GFPL). See also, 'The Ronald Reagan Column,' 18 Jul. 1975, Box 39, Folder 'Reagan - Newspaper Columns', Ron Nessen Papers, GFPL.

39 'Defection of a Russian Seaman', 790.

40 'Russian Defector Gives Witness to the Effectiveness of the Voice of America', Congressional Record, A5978, 23 Sep. 1963, CIA FOIA, CIA-RDP65B00383R000100050038-7.

${ }^{41}$ Wye, 'Vladimir Stepanovich Tarasov', 20 Dec. 1962, FCO 168/911; 'Defection of a Russian Seaman', 790.

${ }^{42}$ Sareen, Bid for Freedom, 13-16.

${ }^{43}$ The New York Times, 22 Dec.1962, 2.

${ }^{44}$ The New York Times, 20 Dec. 1962, 4.

${ }^{45}$ Jugantar (Calcutta), 29 Nov. 1962. 
${ }^{46}$ Eastland to Lodge, Washington, 1 May 1956, Foreign Relations of the United States, 1955-1957, United Nations and General International Matters, Volume XI, Document 23 https://history.state.gov/historicaldocuments/frus1955-57v11/d23. See also, Life, 7 May 1956, 45-46.

${ }^{47}$ The Times of India, 7 Jan. 1963, 7.

${ }^{48}$ The Washington Post, 5 Jan. 1963, A6.

${ }^{49}$ Wye, 'Vladimir Stepanovich Tarasov', 20 Dec. 1962, FCO 168/911.

${ }^{50}$ See, Soviet Embassy to MEA, no. 155, 30 Nov. 1962; MEA to Soviet Embassy, 30 Nov. 1962; and, MEA to Soviet Embassy, 29 Dec. 1962, NAI.

${ }^{51}$ G. D. Khosla foreword in Sareen, Bid for Freedom, iii-iv.

${ }^{52}$ The Times of India, 11 Jan.1963, 8.

${ }^{53}$ Allen to Norris, No. 2402, 24 Dec. 1962, FCO 168/911.

${ }^{54}$ Delhi to IRD, No. 2429, 27 Dec. 1962, FCO 168/911.

${ }^{55}$ Joy to Welser, 18 Jan. 1963, FCO 168/912.

${ }^{56}$ Welser to Kaufman, 28 Dec. 1962; New Delhi to CRO, No. 131, 12 Jan. 1963, FCO 168/911.

${ }^{57}$ Rayner to Joy, 7 Feb. 1963, FCO 168/913.

${ }^{58}$ The Times of India, 4 Mar.1963, 3.

${ }^{59}$ Sareen, Bid for Freedom, 153-54.

${ }^{60}$ The Guardian, 30 Mar. 1963, 7.

${ }^{61}$ The Statesman, 1 Apr. 1963.

${ }^{62}$ The Times of India, 1 Apr. 1963, 6.

${ }^{63}$ King to Joyce, 'Communist Propaganda in the Indian Press', 27 Nov. 1948, FO 1110/44.

64 Patel to Nehru, 'Action against Blitz for Miscellaneous Article', File No. 2/392, Private Papers of Sardar Patel, NAI.

${ }^{65}$ Meeting between James and Freeman, Karachi, 1 and 2 Feb. 1966, FO 371/186952.

66 'India: Dec. 1966', 22 Dec. 1966, DO 196/310.

${ }^{67}$ Smith, Unknown CIA, 13.

${ }^{68}$ Bowles, 'Defection of Svetlana Alliloueva, [sic], 15 Mar. 1967, N[ational] S[security] F[ile] Box 3, Folder Svetlana Alliluyeva (Stalin), Lyndon Baines Johnson Library, Austin, Texas [LBJL].

${ }^{69}$ The Economist, 29 Apr. 1967, 465.

${ }^{70}$ Bowles to Rostow, 18 Mar. 1967, NSF, Box 3, Folder Svetlana Alliluyeva (Stalin), LBJL.

${ }^{71}$ Bowles, 'Defection of Svetlana Alliloueva, [sic], 15 Mar. 1967, NSF, Box 3, Folder Svetlana Alliluyeva (Stalin), LBJL.

${ }^{72}$ Bowles to Rostow, 18 Mar. 1967, NSF, Box 3, Folder Svetlana Alliluyeva (Stalin), LBJL.

${ }^{73}$ Delhi to Washington, 8 Mar. 1967, NSF, Box 3, Folder Svetlana Alliluyeva (Stalin), LBJL.

${ }^{74}$ The Times of India, 7 Jun. 1967, 8.

${ }^{75}$ Schaffer, Chester Bowles, 301.

${ }^{76}$ Delhi to Washington, 9 Mar. 1967, NSF, Box 3, Folder Svetlana Alliluyeva (Stalin), LBJL.

${ }^{77}$ Ibid.; Bowles to Jha, 10 Mar. 1967, see also 'Defection of Svetlana Alliluyeva', 15 Mar. 1967, Box 326, Bowles Papers, Yale University Library.

${ }^{78}$ Sullivan, Stalin's Daughter, 9.

${ }^{79}$ Bendall to Smith, 'Svetlana Stalin', 17 Mar. 1967, FCO 28/397; Trench to Duff, 'Stalin's Daughter', 31 Mar. 1967, FCO 37/76.

${ }^{80}$ Waterfield to Duff, 'Stalin's Daughter', 17 Mar. 1967, FCO 37/76.

${ }^{81}$ Thompson to Rusk, 21 Mar. 1967, NSF, Box 3, Folder Svetlana Alliluyeva (Stalin), LBJL.

${ }^{82}$ Ibid.

${ }^{83}$ See, Lok Sabha Starred Question no. 125, 29 May 1967, AMS, WII/125/47/68, MEA; Lok Sabha exchange between Chagla and Ramamurti, 29 May 1967, AMS, WII/125/47/68, MEA; and Lok Sabha Starred Question No.1, 20 Mar. 1967, WII/125/11/76 P\&I, AMS Division, MEA, NAI.

${ }^{84}$ Bowles to Rusk, 20 Mar. 1967, NSF, Box 3, Folder Svetlana Alliluyeva (Stalin), LBJL.

${ }^{85}$ Ibid.

${ }^{86}$ Bowles to Rusk, 21 Mar. 1967, NSF, Box 3, Folder Svetlana Alliluyeva (Stalin), LBJL.

${ }^{87}$ Conversation between High Commissioner and L.K. Jha, 15 May 1967, FO 37/76.

${ }^{88}$ Waterfield to Duff, 18 Apr. 1967, FCO 37/76; Fall to FO, 19 Apr. 1967, FCO 28/397.

${ }^{89}$ Bowles to Rusk, 31 Mar. 1967, NSF, Box 3, Folder Svetlana Alliluyeva (Stalin), LBJL.

${ }^{90}$ Gore-Booth to Hood, 'Miss Stalin's Defection', 27 Apr.1967, FO 95/14.

${ }^{91}$ Memorandum, 'Svetlana', unsigned and undated, FO 95/14.

${ }^{92}$ McMinnies, 'Publicity in India for Soviet Writers' Trial', 3 Apr. 1968; Gopal Mittal, 'Unending Soviet War on Intellectuals', FCO 168/3402.

${ }_{93}$ Greenhill to P.U.S., 'Miss Stalin's Defection', 28 Apr. 1967, FO 95/14. 
${ }^{94}$ The Times of India, 7 Jun. 1967, 8.

${ }^{95}$ Giffard to Greenhill, 'Svetlana Stalin's Book', 20 Sep. 1967, FCO 28/397; Day to Stewart, 22 Sep. 1967, FCO 28/397.

${ }_{96}$ Minute by McMinnies, 20 Oct.1969, FCO 37/375.

${ }^{97}$ The National Review, 19 (18), 9 May 1967,1.

${ }^{98}$ The Times of India, 7 Jun. 1967, 8.

99 Harrison to FO, 'Svetlana Stalin', 27 May 1967, FCO 28/397.

${ }^{100}$ Daily Mail, 3 Nov. 1984.

${ }^{101}$ The Times of India, 21 Dec. 1967, 1.

${ }^{102}$ Indian Embassy (Moscow) Political Report for Dec. 1967, 9 Jan. 1968, Monthly Political Reports (Other than Annual) from Embassy of India, Moscow, File No. HI/1012(57)/67, R\& I, MEA, NAI.

${ }^{103}$ Ibid.

${ }^{104}$ See, Smith, CIA Agent in India.

${ }^{105}$ Indian Embassy (Moscow) Political Report for Dec. 1967, 9 Jan. 1968, Monthly Political Reports (Other than Annual) from Embassy of India, Moscow, File No. HI/1012(57)/67, R\& I, MEA, NAI.

${ }^{106}$ The Times of India, 21 Dec. 1967, 1.

107 The Times, 22 Dec. 1967, 1.

${ }^{108}$ The Times of India, 21 Dec. 1967, 1.

${ }^{109}$ Rimington, Open Secret, 74.

110 Joseph N. Greene, JR., 12 Mar. 1993, Foreign Affairs Oral History Project, INTERNET, http://memory.loc.gov/ammem/collections/diplomacy/ (accessed 7 Feb. 2013).

${ }^{111}$ The Times of India, 22 Dec.1967, 1.

${ }^{112}$ Ibid.

113 Ibid.

${ }^{114}$ The Times of India, 27 Dec. 1967, 9.

${ }^{115}$ Clive to Jackson, 'Publicity for Mr. Oualouzade', 5 Jan. 1968; Payne to Welser and Clive, 8 Jan. 1968, FCO 168/2850.

116 McMinnies to Lancashire, 22 Dec. 1968; Lancashire to McMinnies , 4 Jan. 1968, FCO 168/2850.

117 Tucker to Hamilton, 20 Feb. 1968; O'Connor Howe minute to Bayne, 29 Nov. 1968, FCO $168 / 2850$.

${ }^{118}$ Handwritten note from Peck to Greenhill, 'Publicity for the Soviet Defector Mr. Aziz Ulugzade', 12 Feb. 1968, FCO 168/2850.

${ }^{119}$ The Times of India, 28 Dec. 1967, 6.

${ }^{120}$ The Times of India, 28 Dec. 1967, 12.

${ }^{121}$ The Times of India, 28 Dec. 1967, 1.

${ }^{122}$ The Times of India, 29 Dec. 1967, 5.

123 'Instructions against Grant of Asylum', 30 Dec. 1967, Pakistan-I, File No. PI/452/1/68, MEA, NAI.

${ }^{124}$ Cole to Hunt, 'Political Asylum in India', 5 Jan. 1968, FCO 37/62.

${ }^{125}$ Hunt to Cole, 4 Mar. 1968, FCO 37/62.

${ }^{126}$ Cole to Hunt, 'Political Asylum in India' 9 \& 13 Mar. 1968, FCO 37/62.

${ }^{127}$ Lok Sabha, Unstarred Question No. 360, 14 Feb. 1968.

${ }^{128}$ Haksar to Gandhi, 19 Nov. 1974, P. N. Haksar Papers, III Instalment, Subject File 269, NMML.

${ }^{129}$ The Times of India, $10 \mathrm{Feb} .1970,1$.

${ }^{130}$ The Times of India, 21 Jun. 1972, 1.

${ }^{131}$ Hunting, 'Amnesty International Report 1975/1976', 29 Nov. 1976, FCO 37/1933.

132 Vance to New Delhi, 'Press Guidance', 4 Feb. 1977, Document no. 1977STATE025389, US National Archives, College Park, Maryland.

\section{References}

1. Abraham, Itty, 'From Bandung to NAM: Non-alignment and Indian Foreign Policy, 194765,' Commonwealth \& Comparative Politics, (46,2) (2018), 195-219.

2. Aldrich, Richard. 'Policing the Past: Official History, Secrecy and British Intelligence since 1945’, English Historical Review Vol. CXIX No. 483 (Sept. 2004), 922-953.

3. Alliluyeva, Svetlana. Only One Year (New York: HarperCollins, 1969). 
4. Andrew, Christopher. The Defence of the Realm: The Authorized History of MI5 (London: Allen Lane, 2009).

5. Andrew, Christopher and Mitrokhin, Vasili. The Mitrokhin Archive II: The KGB and the Wider World (London: Aleen Lane, 2005).

6. Baghavan, Manu. The Peacemakers; India and the Quest for One World (New Delhi: HarperCollins, 2012).

7. Balachandran, Vappala. National Security and Intelligence Management: A New Paradigm (Mumbai: Indus Source books, 2014).

8. Blake, George. No Other Choice: An Autobiography (London: Jonathan Cape, 1990).

9. Bradley, Mark Philip. The World Reimagined: Americans and Human Rights in the Twentieth Century (Cambridge: Cambridge University Press, 2016).

10. Carruthers, Susan L. Cold War Captives: Imprisonment, Escape and Brainwashing (Berkley: University of California Press, 2009).

11. Chamberlin, Paul Thomas. The Cold War's Killing Fields: Rethinking the Long Peace (New York: HarperCollins, 2018).

12. Cherkashin, Victor. Spy Handler: Memoir of a KGB Officer - The True Story of the Man Who Recruited Robert Hanssen and Aldrich Ames (London: Basic Books, 2005).

13. Codell, Julie. F. (ed.). Imperial Co-Histories National Identities and the British and Colonial Press (London: Fairleigh Dickinson University Press, 2003).

14. Conboy, Kenneth and Morrison, James, The CIA's Secret War in Tibet (Lawrence, KS, 2002).

15. Crile, George. Charlie Wilson's War: The Extraordinary Story of the Covert Operation that Changed the History of our Times (New York: Atlantic Books, 2002).

16. Dauer, Richard P. A North-South Mind in an East-West World: Chester Bowles and the Making of United States Cold War Foreign Policy, 1951-1969 (Westport, CN, 2005).

17. Davies, Philip and Gustafson, Kristian (eds.). Intelligence Elsewhere: Spies and Espionage Outside the Anglosphere (Washington, DC: Georgetown University Press, 2013).

18. Den Heijer, Maarten. 'Diplomatic Asylum and the Assange Case', Leiden Journal of International Law (26), (2013), 399-425.

19. Finkelstein, D., and Peers, D. M. (eds.), Negotiating India in the Nineteenth-Century Media (London, Macmillan, 2000).

20. Guyot-Réchard, Bérénice. Shadow States: India, China and the Himalayas, 1910-1962 (Cambridge: Cambridge University Press, 2017).

21. Jacobs, Justin M. 'Exile Island: Xinjiang Refugees and the "One China" Policy in Nationalist Taiwan, 1949-1971', Journal of Cold War Studies, vol. 18, no. 1 (Winter 2016), 188-218.

22. Jeffrey, Keith. MI6: The History of the Secret Intelligence Service (London: Bloomsbury, 2010).

23. Jeffreys-Jones, Rhodri. Cloak and Dollar: A History of American Secret Intelligence. (New Haven: Yale University Press, 2003).

24. Horne, Alistair. Macmillan, 1957-1986: Vol. 2 of the Official Biography (Macmillan, 1989). 
25. Kalugin, Oleg. Spymaster: My Thirty-Two Years in Intelligence and Espionage against the West (New York, 2009).

26. Kaul, Chandrika. Reporting the Raj, The British Press and India 1880-1922 (Manchester: Manchester University Press, 2003).

27. Kaul, Chandrika. Media and the British Empire (London: Palgrave, 2006).

28. Kaul, Chandrika. Communication. Media and the Imperial Experience: Britain and India in the Twentieth Century (Basingstoke: Palgrave Macmillan, 2014).

29. Keys, Barbara J. Reclaiming American Virtue: The Human Rights Revolution of the 1970s (Cambridge, Mass.: Harvard University Press, 2014).

30. Knaus, John Kenneth, Orphans of the Cold War: America and the Tibetan Struggle for Survival (New York, 1999).

31. Knight, Amy. How the Cold War Began: The Igor Gouzenko Affair and the Hunt for Soviet Spies (New York: Carroll \& Graf, 2005).

32. Knightley, Philip. Philby: KGB Masterspy (London: Andre Deutsch, 2003).

33. Krasnov, Vladislav. Soviet Defectors: The KGB Wanted List (Stanford, CA: Hoover Institution Press, 1986).

34. Kux, Dennis. India and the United States: Estranged Democracies, 1941- 1991 (Washington, DC: National Defense University Press, 1993).

35. Le Carrè, John. The Secret Pilgrim (London: Hodder \& Stoughton, 1991).

36. Le Carrè, John. Tinker Tailor, Soldier Spy (London: Hodder and Stoughton. 1974).

37. Lee, Christopher (ed)., Making a World After Empire: The Bandung Moment and its Political Afterlives (Athens, OH: Ohio University Press, 2010).

38. Lewis, Su Lin and Stolte, Carolien (eds.), 'Special Issue: Other Bandungs: Afro-Asian Internationalisms in the Early Cold War', Journal of World History, (30, 1-2) (June 2019).

39. Lownie, Andrew. Stalin's Englishman: The Lives of Guy Burgess (London: Hodder, 2016).

40. Lüthi, Lorenz. 'The non-aligned: Apart from and still within the Cold War' in Nataša Mišković, Harald Fischer-Tiné and Nada Boškovska (eds.), The Non-Aligned Movement and the Cold War: Delhi-Bandung-Belgrade (Abingdon; Routledge, 2014), 97-113.

41. Macintyre, Ben. A Spy Amongst Friends; Kim Philby and the Great Betrayal (London: Bloomsbury, 2015).

42. McGarr, Paul M. The Cold War in South Asia: Britain, the United States and the Indian Subcontinent, 1945-1965 (Cambridge, 2013).

43. McGarr, Paul M. "QQuiet Americans in India”: The Central Intelligence Agency and the Politics of Intelligence in Cold War South Asia.' Diplomatic History, 38 (5), (November 2014).

44. McMahon, Robert J. The Cold War on the Periphery: The United States, India and Pakistan (New York, 1994). 
45. McMahon Robert. (ed)., The Cold War in the Third World (New York: Oxford University Press, 2013).

46. Mišković, Nataša, Fischer-Tiné, Harald, and Boškovska, Nada (eds.), The Non-Aligned Movement and the Cold War: Delhi-Bandung-Belgrade (Abingdon; Routledge, 2014).

47. Petrov, Vladimir and Evdokia. Empire of Fear (London: Andre Deutsch, 1956).

48. Prados, John. Safe for Democracy: The Secret Wars of the CIA (Chicago: Ivan \& Dee, 2006).

49. Pullin, Eric D. 'Money Does Not Make Any Difference to the Opinions That We Hold': India, the CIA, and the Congress for Cultural Freedom, 1951-58, Intelligence and National Security, (26,2-3) (2011), 377-398.

50. Richelson, Jeffrey. The US Intelligence Community (Boulder, CO: Westview Press, 2008.

51. Rimington, Stella. Open Secret: The Autobiography of the Former Director-General of MI5 (London: Arrow Books, 2002).

52. Sareen, C. L. Bid for Freedom: USSR vs. Tarasov (Englewood Cliffs, NJ: Prentice Hall, 1966).

53. Schaffer, Howard. Chester Bowles: New Dealer in the Cold War (Cambridge Mass.: Harvard University Press, 1993).

54. Smith, John D. I Was a CIA Agent in India (New Delhi: New Age Printing, 1967).

55. Smith, Russell Jack. The Unknown CIA: My Three Decades with the Agency (New York, 1992).

56. Sullivan, Rosemary. Stalin's Daughter: The Extraordinary and Tumultuous Life of Svetlana Stalin (London: Fourth Estate, 2015).

57. Synder, Sarah B. Human Rights Activism and the End of the Cold War: A Transnational History of the Helsinki Network (Cambridge: Cambridge University Press, 2011.)

58. Thorpe, D. R. Supermac: The Life of Harold Macmillan (Pimlico, 2011).

59. Tromly, Benjamin. 'Ambivalent Heroes: Russian Defectors and American Power in the Early Cold War', Intelligence \& National Security (2018), DOI: 10.1080/02684527.2018.1442296.

60. US House of Representatives. 'Defection of a Russian Seaman: testimony of Vladislaw Stepanovich Tarasov', Hearing before the Committee of Un-American Activities, EightyEight Congress, First Session, 19 September 1963 (Washington: GPO, 1963).

61. Volodarsky, Boris. Stalin's Agent: The Life and Death of Alexander Orlov (Oxford: OUP, 2015).

62. Wasif Khan, Sulmaan. Muslim, Trader, Nomad, Spy: China's Cold War and the People of the Tibetan Borderlands (Chapel Hill, NC: University of North Carolina Press, 2015).

63. Westad, Odd Arne. The Cold War: A World History (London: Allen Lane, 2017).

64. Woodward, Bob. Veil: The Secret Wars of CIA 1981-1987 (New York: Simon and Schuster, 1987). 